\title{
ANALISIS INTEGRASI PASAR SPASIAL KOMODITI PANGAN ANTAR PROVINSI DI INDONESIA
}

\author{
Arnanto $^{1}$, Sri Hartoyo ${ }^{2}$, Wiwiek Rindayati ${ }^{2}$ \\ ${ }^{1}$ Staf pada Kementerian Perdagangan dan Mahasiswa Program Studi Ilmu Ekonomi, \\ FEM IPB \\ ${ }^{2}$ Staf Pengajar FEM IPB
}

Artikel diterima Mei 2014

Artikel disetujui untuk dipublikasikan Desember 2014

\begin{abstract}
Food prices stabilization through the food production and trade to fulfillment consumption in terms of both availability and accessibility food is government major problem. Government's ability to determine an appropriate pricing policy depends on market structure, behavior and effectiveness. Trade barriers and market failure reduction, improved access information would make market integration effective and efficient. This study aims to analyze the market integration and the price transmission elasticity that occurs between regions in Indonesia. Using Ravallion integration analysis and a span from 2009 to 2013 on 33 provinces retail prices data in Indonesia to capture level integration and price transmission between regions. The results showed in the rice shows that Jakarta and South Sulawesi region is becoming the leading market and Jakarta for sugar market those integrated with most areas in Indonesia. Sugar and rice have a better degree of integration than soya. Integration analysis with Ravallion models cannot explain two areas integrated or not. It is necessary to study towards further for East Java in terms of either regional autonomy policy or any market failure that occurs in order to find a policy solution to be more integrated.
\end{abstract}

Key words : Food, Market integration, Ravallion model

\section{PENDAHULUAN}

Harga dari komoditas meningkat tajam sejak tahun 2002, dan kenaikan yang paling tinggi terjadi selama periode dari Januari 2006 sampai Juni 2008. Dalam rangka mengatasi permasalahan stabilisasi harga tersebut, pemerintah telah mengeluarkan Peraturan Menteri Koordinator Bidang Perekonomian No. KEP-28/M.EKON/05/2010 tentang Tim Koordinasi Stabilisasi Pangan Pokok. Tim tersebut bertugas merencanakan dan merumuskan kebijakan stabilisasi pemenuhan kebutuhan dan harga pangan pokok, mengoordinasikan pelaksanaan stabilisasi kebutuhan dan melakukan pemantauan dan evaluasi stabilitas harga pangan pokok beras, gula, minyak goreng, terigu, kedelai,daging sapi, daging ayam, dan telur ayam. Disamping produksi pangan yang tidak mencukupi kurang meratanya penyediaan pangan bagi masyarakat juga menjadi pemicu kenaikan harga pangan, Fakta di lapangan menunjukkan bahwa sistem produksi dan sistem distribusi beberapa pangan terganggu karena kualitas sarana dan prasarana transportasi banyak rusak.

Belum adanya perda khusus yang mengatur perdagangan hasil pertanian 
antar daerah memerlukan perhatian sehingga dapat tercipta perdagangan antar wilayah yang efektif dan efisien. Koordinasi antar wilayah dalam rangka peningkatan perdagangan dan pemenuhan kebutuhan produk pertanian antar daerah produsen harus menjadi perhatian baik pemerintah pusat maupun pemerintah daerah.

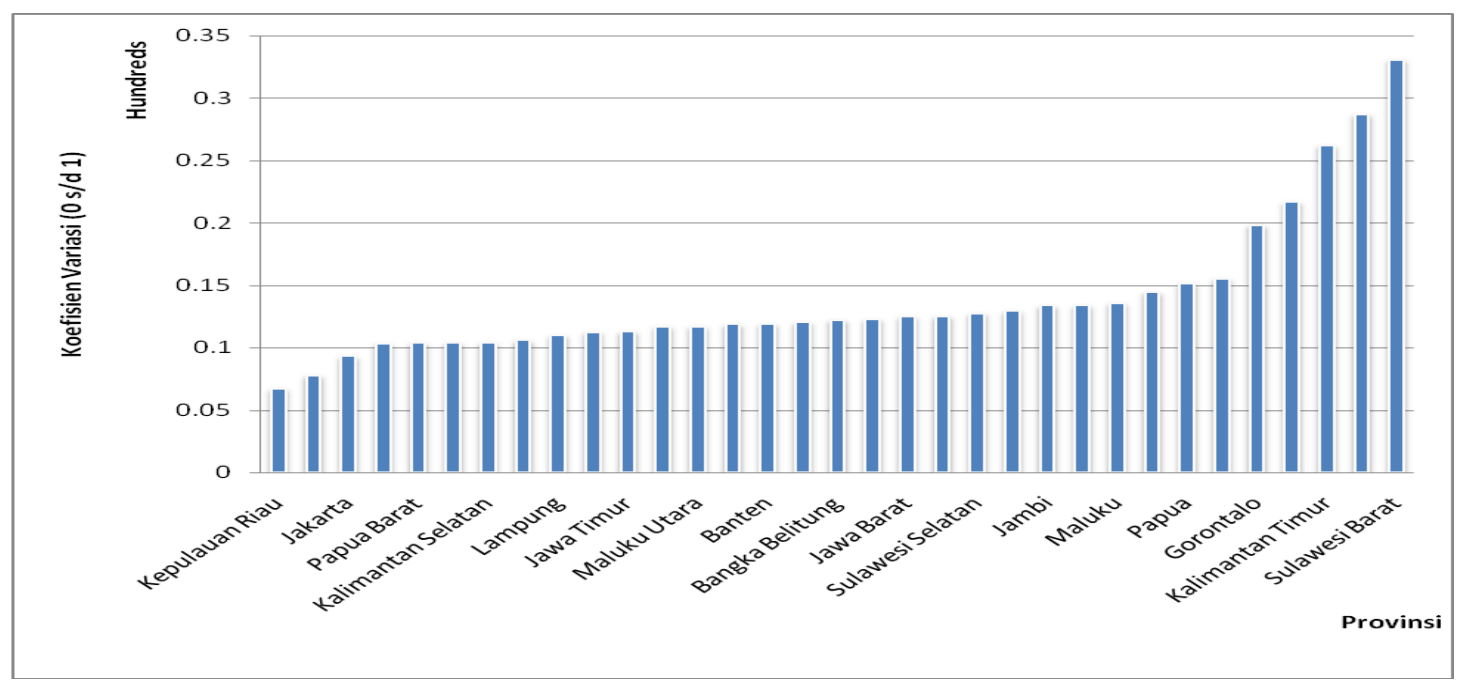

Sumber : Direktorat Bapokstra, Kementerian Perdagangan, 2014

Gambar 1. Koefisien Variasi Harga Gula di 33 Provinsi di Indonesia Tahun 2013

Pengendalian harga pangan yang dilakukan oleh pemerintah terjadi karena tidak seimbangnya supply dari produsen pertanian dengan trend permintaan terhadap produk tersebut. Kebijakan stabilisasi harga yang dilakukan oleh pemerintah bertujuan untuk memenuhi aspek availability dan accessability to food. Ketersediaan bahan pangan dan juga accessability baik fisik maupun ekonomi disetiap daerah dan setiap waktu dari konsumen dalam memperoleh bahan pangan. Akses fisik berarti kemudahan dalam memperoleh bahan pangan sedangkan akses ekonomi berkaitan dengan daya beli masyarakat.

Kebijakan stabilisasi harga pada produk pangan sangat sulit untuk dilaksanakan secara efektif dan efisien karena berbagai alasan. Luasan negara Indonesia yang mencakup daerah lautan yang luas menyebabkan proses distribusi yang menjadi sulit, produksi dan konsumsi bahan pangan yang tidak seimbang. Letak pasar konsumen yang terpisah sangat jauh dengan daerah produksi sehingga tingginya biaya dalam pengiriman membuat lemahnya integrasi pasar bahan pangan, implementasi dari kebijakan stabilisasi harga akan lebih efektif pada pasar yang terintegrasi dibanding yang tidak terintegrasi. Pada pasar yang terintegrasi, penerapan intervensi pemerintah disalurkan kepada pasar-pasar lainnya sehingga pelaksanaan kebijakan harga dapat dilakukan dengan biaya yang lebih murah. Derajat integrasi pasar dapat memberikan informasi kepada pemerintah, sehingga apabila terjadi gejolak harga di suatu daerah dapat dilakukan aksi efektif agar gejolak harga tersebut tidak meluas dan menjadi gejolak nasional.

Struktur alur perdagangan yang kurang baik akan menyebabkan harga menjadi fluktuatif, volatilitas harga dapat dilihat dari nilai koefisien variasi pada komoditi pangan tiap provinsi. Perbedaan nilai koefisien variasi tiap daerah memperlihatkan bahwa kemampuan tiap provinsi dalam meredam gejolak harga 
berbeda (Gambar 1). Untuk komoditi gula, nilai koefisien variasi terendah terdapat di Kepulauan Riau dengan 0.0671 dan nilai tertinggi Sulawesi Barat 0.3307. Apabila dibandingkan dengan Jawa Timur sebagai produsen gula terbesar di Indonesia dengan koefisen 0.1130, kemampuan Sulawesi Barat sebagai daerah konsumen dalam meredam fluktuasi sangat rendah. Nilai koefisien variasi memperlihatkan perbedaan kemampuan provinsi dalam meredam fluktuasi harga serta perbedaan kemampuan daerah dalam mencari supply komoditi pangan ketika permintaan tinggi.

Dari kajian Worldbank tentang pengembangan sektor perdagangan tahun 2011 meneliti mengenai integrasi spasial komoditi kedelai, jagung, beras, gula dan minyak goreng. Menyimpulkan bahwa untuk komoditas yang menerima banyak intervensi dari pemerintah seperti beras tingkat integrasinya akan sedikit lebih tinggi. Tingkat integrasi spasial antar provinsi cukup signifikan sebagaimana ditunjukan pergerakan harga bersama yang kuat, pada komoditi gula mempunyai angka $83 \%$ pasangan pasar provinsi terintegrasi, beras $76 \%$ pasangan terintegrasi, minyak goreng $30 \%$ pasangan terintegrasi, jagung $28 \%$ pasangan terintegrasi dan komoditi kedelai $26 \%$ pasangan pasar provinsi terintegrasi.

Berdasarkan latar belakang dan identifikasi serta rumusan masalah yang telah diuraikan maka tujuan dari penelitian ini adalah menganalisa integrasi pasar yang terjadi antar wilayah di Indonesia dan menganalisis besaran elastisitas transmisi perubahan harga didaerah akibat perubahan harga di pasar acuan serta melihat dimanakah daerah yang menjadi pasar acuan untuk ketiga komoditi tersebut.

\section{METODE PENELITIAN}

Dalam menghindari pembahasan melebihi tujuan penelitian, maka diberikan batasan penelitian. Untuk pengujian integrasi spasial menggunakan harga riil komoditi yang diteliti yaitu beras, gula dan kacang kedelai sedangkan yang dianalisis adalah 33 provinsi di Indonesia, sementara periode analisis dalam penelitian ini adalah tahun 2009 s/d tahun 2013. Metode analisis yang digunakan adalah analisis integrasi menggunakan model ravallion yaitu metode yang digunakan untuk mengetahui integrasi spasial antar provinsi di Indonesia. Provinsi yang dijadikan acuan menggunakan data daerah yang memiliki tingkat produksi, konsumsi dan nilai perdagangan yang menjadi perhatian dari pemerintah yaitu Jawa Barat, Jawa Timur, Jawa Tengah, Sulawesi Selatan, Sumateras Selatan, Lampung dan DKI Jakarta..

\section{Model Ravallion}

Model Ravallion (1986) telah digunakan secara luas, dikembangkan, dan didiskusikan dalam analisis integrasi pasar. Secara umum model persaman matematik yang dikembangkan oleh Heytens (1986), adalah sebagai berikut.:

$$
\begin{aligned}
& R=f\left(P_{1}, P_{2}, P_{3}, \ldots, P_{n}, X_{i}\right) \\
& P_{i}=f_{i}\left(R, X_{i}\right), i=2, \ldots \ldots, n \ldots
\end{aligned}
$$

Dalam hal ini $n$ pasar provinsi dengan harga $\mathrm{P}$; $\mathrm{R}$ adalah harga dileading market (pasar acuan). $X_{i}$ adalah factor musiman dan faktor-faktor lain yang mungkin mempengaruhi harga di pasar i (termasuk leading market dan pasar di daerah lainnya). Karena persamaan (1) dan (2) hanya mengukur harga pada waktu sekarang, maka memasukkan pengaruh time lag pada harga akan memberikan struktur yang lebih dinamis. Namun jika periode lag terlalu panjang model akan menjadi rumit, sehingga diasumsikan harga pada tiap-tiap pasar hanya memiliki satu fase lag. Secara lebih spesifik persamaan model Ravallion dalam studi ini dapat ditulis sebagai berikut:

$$
\begin{aligned}
& P_{t}=a_{i} P_{t-1}+b_{i 0} R_{t}+b_{i 1} R_{t-1}+c_{i} X_{t}+\varepsilon_{t} \ldots(3) \\
& \text { untuk } i=1,2, \ldots, n \\
& \text { Persamaan (3) sensitif terhadap }
\end{aligned}
$$
terjadinya multikolinieritas ketika harga 
pasar di provinsi dan acuan berkorelasi kuat. Menduga dalam bentuk pembedaan pertama (first difference) akan mengurangi pengaruh multikolinieritas karena $\left(\mathrm{R}_{\mathrm{t}}-\mathrm{R}_{\mathrm{t}-1}\right)$ dan $\left(\mathrm{P}_{\mathrm{t}}-\mathrm{P}_{\mathrm{t}-1}\right)$ biasanya berkorelasi lemah dibandingkan $\mathrm{R}_{\mathrm{t}}$ dan Pt. Transformasi ini akan menghasilkan:

$\mathrm{P}_{\mathrm{t}}-\mathrm{P}_{\mathrm{t}-1}=\mathrm{a}_{\mathrm{i}} \mathrm{P}_{\mathrm{t}-1}-\mathrm{P}_{\mathrm{t}-1}+\mathrm{b}_{\mathrm{i} 0} \mathrm{R}_{\mathrm{t}}+\mathrm{b}_{\mathrm{i} 1} \mathrm{R}_{\mathrm{t}-1}+\mathrm{c}_{\mathrm{i}} \mathrm{X}_{\mathrm{t}}+\varepsilon_{\mathrm{t}}$ (4)

Jika diasumsikan bahwa deret waktu di pasar lokal (P) dan di pasar acuan (R) mempunyai pola musiman yang sama, sehingga tidak perlu memasukkan peubah dummy untuk musiman (Xt). Maka persamaan menjadi:

$\mathrm{P}_{\mathrm{t}}-\mathrm{P}_{\mathrm{t}-1}=\mathrm{a}_{\mathrm{i}} \mathrm{P}_{\mathrm{t}-1}-\mathrm{P}_{\mathrm{t}-1}+\mathrm{b}_{\mathrm{i} 0} \mathrm{R}_{\mathrm{t}}+\mathrm{b}_{\mathrm{i} 1} \mathrm{R}_{\mathrm{t}-1}+\varepsilon_{\mathrm{t}}$

Kemudian disederhanakan menjadi

$P_{t}=b_{1} P_{t-1}+b_{2}\left(R_{t}-R_{t-1}\right)+b_{3} R_{t-1}+\varepsilon$

Secara umum, persamaan

menunjukkan bagaimana harga di suatu pasar (pasar acuan) mempengaruhi pembentukan harga di pasar lain (pasar lokal) dengan mempertimbangkan pengaruh harga pada waktu tertentu (t) dengan harga pada pada waktu sebelumnya (t-1). Penetapan harga pada waktu sebelumnya (t-1) dalam rentang waktu tertentu bertujuan untuk melihat fluktuasi harga yang terjadi. Untuk menunjukkan pengaruh harga masa lalu pasar provinsi dan harga masa lalu pasar acuan terhadap pembentukkan harga produsen di pasar regional pada waktu tertentu digunakan Index of Market Connection (IMC). IMC dikembangkan oleh Timmer (1986) yang didefinisikan sebagai rasio koefisien pasar provinsi dengan koefisien pasar acuan, yaitu:

$$
\mathrm{IMC}=\frac{b_{1}}{b_{3}}
$$

Menurut Timmer (1986), IMC dengan nilai kurang dari satu mengindikasikan terjadinya integrasi jangka pendek. Secara umum, jika nilai IMC semakin mendekati nol maka semakin tinggi derajat integrasi. Dalam hal ini $b_{2}$ merupakan ukuran derajat perubahan harga di pasar acuan yang ditransmisi ke pasar regional. Parameter ini mengukur integrasi jangka panjang dan nilai yang diharapkan adalah sama atau dekat dengan 1. Jika nilai koefisien $b_{2}$ sama dengan satu $\left(b_{2}=1\right)$, maka kedua pasar terintegrasi sempurna dalam jangka panjang. Perbedaaan diantara kedua indikator ini adalah bahwa $b_{2}$ menunjukkan berapa persen perubahan harga yang terjadi di pasar acuan ditransmisikan ke pasar provinsi lainnya.

Dalam pendekatan ini, hipotesis integrasi jangka pendek dirumuskan sebagai berikut:

$\mathrm{H}_{0}: \mathrm{b}_{1}=0$

Untuk uji statistik digunakan:

$\mathrm{t}_{\text {hitung }}=\frac{b_{1}-0}{S\left(b_{1}\right)}$

Bila hipotesis nol ditolak artinya pasar tidak terintegrasi dalam jangka pendek. Untuk integrasi jangka panjang dirumuskan hipotesis:

$\mathrm{H}_{0}: \mathrm{b}_{2}=1$

Nilai thitung diperoleh dari:

$\mathrm{t}_{\text {hitung }}=\frac{b_{2}-1}{S\left(b_{2}\right)}$

Bila hipotesis nol ditolak berarti pasar tidak terintegrasi pada jangka panjang.

\section{HASIL DAN PEMBAHASAN}

\section{Integrasi Jangka Pendek Pasar Beras di Indonesia}

Analisis integrasi pasar pada komoditi beras menggunakan 8 provinsi sebagai pasar acuan yaitu Jawa Barat, Jawa Timur, Jawa Tengah, Sulawesi Selatan, Sumateras Selatan, Lampung dan DKI Jakarta. Sedangkan provinsi lainnya sebagai pasar local yang diasumsikan mengacu harga terhadap pasar acuan. Nilai koefisien IMC menunjukan bahwa integrasi jangka pendek tidak terjadi 
diantara produsen beras di Indonesia. Nilai IMC yang lebih dari 1 menunjukan integrasi yang sangat lemah diantara daerah produsen hal ini disebabkan karena tidak adanya atau sangat kecilnya arus perdagangan diantara para produsen beras di Indonesia. Produsen yang surplus akan mencari daerah yang deficit untuk menjadi partner dalam berdagang karena permintaan dating dari daerah tersebut. Hal ini dapat terlihat dari hubungan antara provinsi Jawa Barat dan DKI Jakarta, dimana nilai IMC yaitu sebesar 3,06 dan 3,29 diantara keduanya memperlihatkan nilai IMC yang kecil. Jarak diantara keduanya dan dimana Jawa Barat merupakan salah satu pemasok beras ke Jakarta menjadi salah satu penyebab terjadinya nilai IMC yang rendah.

Nilai IMC dimana Sumatera Utara menjadi pasar pengikut pada Lampiran 1 menunjukan bahwa nilai IMC yang signifikan dan memiliki nilai yang mendekati 1 menunjukan bahwa Sumatera Utara memiliki tingkat keterpaduan pasar dengan provinsi produsen lainnya yaitu Jawa Barat, Jawa Timur, Jawa Tengah, Makasar, Sumatera Selatan, Lampung dan Jakarta. Namun sebagai pasar acuan Sumatera Utara tidak terintegrasi dengan baik dengan pasar produsen lainnya, hal ini dapat disimpulkan bahwa Sumatera Utara dalam jangka pendek tidak berperan terhadap pembentukan harga di daerah produsen namun pembentukan harga di Sumatera Utara dipengaruhi oleh daerah acuan. Provinsi yang terintegrasi signifikan walupun lemah terhadap pasar acuan yaitu Jawa Barat, Jawa Timur, Jawa Tengah, Lampung dan Jakarta. Sebagai lumbung padi nasional Jawa Barat sebagai daerah acuan tidak terintegrasi dengan Jawa Tengah dan Jawa Timur namun terintegrasi sebagai daerah pengikut. Hal ini dapat disimpulkan bahwa pembentukan harga di Jawa Barat sebagai daerah produsen dipengaruhi oleh harga di Jawa Tengah dan Jawa Timur.
Derajat integrasi jangka pendek yang diperlihatkan dimana delapan provinsi acuan dan 25 provinsi sebagai pengikut memperlihatkan bahwa nilai IMC yang paling baik yaitu adalah provinsi Aceh dan Riau dengan nilai mendekati angka 1, ini dapat disimpulkan bahwa dalam jangka pendek kedua provinsi itu terintegrasi walaupun secara lemah dengan daerah acuan. Integrasi yang paling baik terlihat pada Jawa Barat, Jawa Tengah dan Jakarta sebagai daerah acuan, nilai IMC ketiga daerah tersebut memiliki nilai paling kecil dibandingkan daerah acuan lainnya. Bila melihat nilai IMC dari seluruh daerah yang diuji dapat disimpulkan bahwa dalam jangka pendek komoditi beras tidak terintegrasi dengan baik atau terintegrasi secara lemah dan sangat lemah. Hal ini diperlihatkan dengan angka IMC yang lebih dari 1, permasalahan di negara berkembang seperti tingkat infrastruktur dan tingkat komunikasi perdagangan yang masih rendah menyebabkan efisiensi perdagangan dan informasi belum berjalan dengan baik.

Dengan adanya berbagai kebijakan dalam rangka stabilisasi harga, beras di suatu daerah lebih tergantung oleh harga di daerah tersebut pada periode sebelumnya. Kenaikan harga pada provinsi produsen maupun konsumen yang dijadikan acuan dalam jangka pendek tidak akan mempengaruhi harga di provinsi lainnya. Dalam jangka pendek harga disetiap provinsi tidak dipengaruhi oleh provinsi acuan namun dipengaruhi oleh harga di daerah tersebut pada periode sebelumnya.

\section{Integrasi Jangka Panjang Pasar Beras di Indonesia}

Nilai koefisen $b_{2}$ pada Lampiran 1 sebagai hasil regresi menunjukan bahwa dalam jangka panjang Sulawesi Selatan dan DKI Jakarta memilki nilai $b_{2}$ yang tinggi dan signifikan pada taraf 5 persen terintegrasi terhadap provinsi produsen. 
Sulawesi Selatan terintegrasi terhadap Jawa Barat, Jawa Tengah, Sumatera Utara, Sumatera Selatan, dan DKI Jakarta. Dengan nilai $\mathrm{b}_{2}$ tertinggi yaitu Jawa Barat 0,924 dan terendah Jawa Tengah 0,736. Ini dapat diartikan bahwa apabila harga beras di Sulawesi Selatan naik sebesar 1 persen maka harga di Jawa Barat akan naik sebesar 0,924 persen dan Jawa tengah akan naik sebesar 0,736 persen.

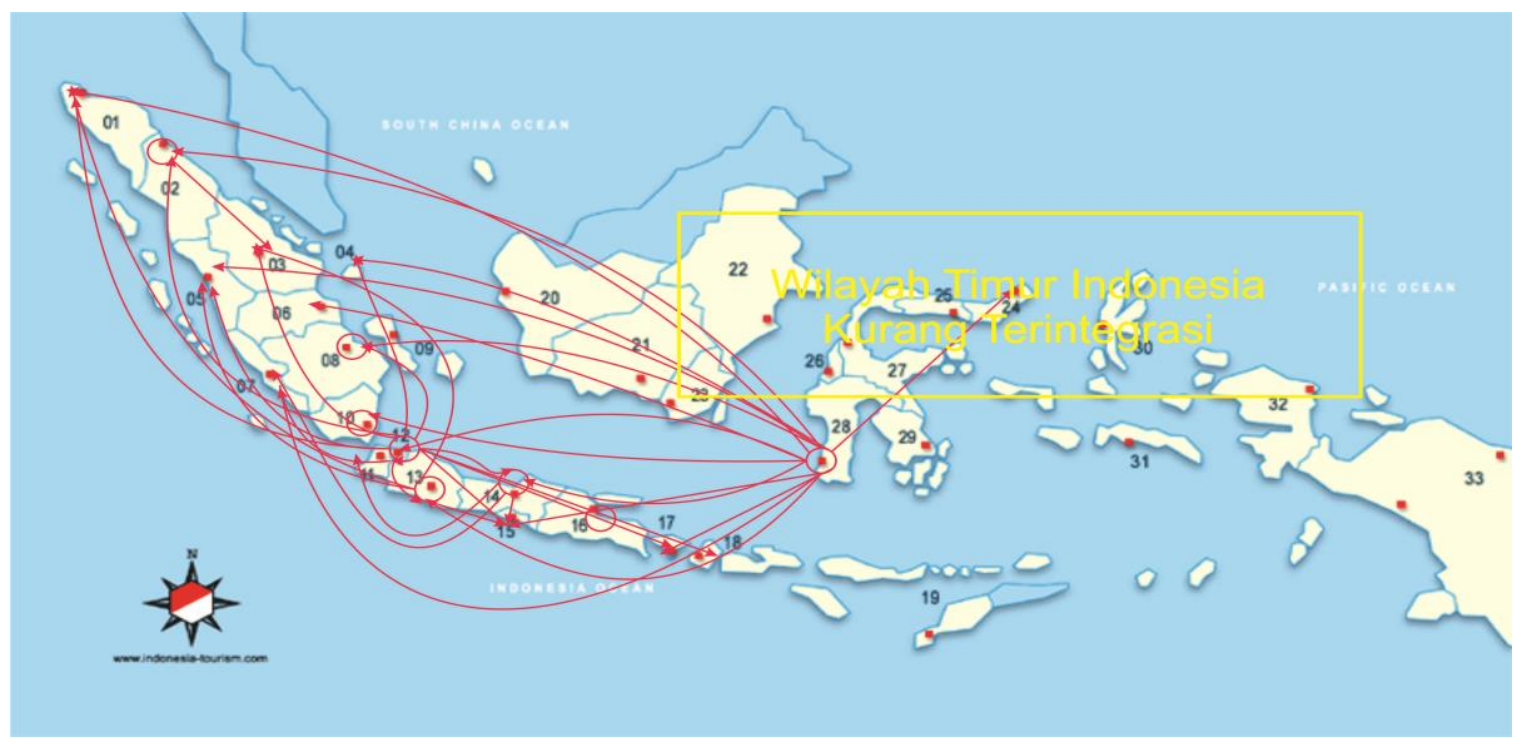

Gambar 2. Elastisitas Transmisi Harga Beras di 33 Provinsi di Indonesia

DKI Jakarta sebagai provinsi acuan dan sebagai daerah yang deficit terhadap beras memiliki nilai $b_{2}$ yang terbukti signifikan terhadap daerah produsen. Jakarta terintegrasi dengan Jawa Barat, Jawa Tengah, Sumatera Utara dan Sumatera Selatan. Nilai tertinggi yaitu dengan Jawa Barat 0,921 dan terendah dengan Sumatera Selatan 0,625. Hubungan perdagangan dengan Jawa Barat sebagai provinsi yang paling dekat dengan Jakarta menyebabkan integrasi terjadi diantara kedua daerah tersebut. Nilai 0,921 memperlihatkan bahwa harga beras di Jawa Barat sebagai lumbung padi nasional lebih dipengaruhi oleh harga di konsumen di Jakarta, bila harga di Jakarta nilai 1 persen maka harga di Jawa Barat akan naik sebesar 0,921 persen. Jakarta sebagai provinsi acuan dalam jangka panjang terintegrasi dengan 25 daerah lainnya namun dalam jangka pendek nilai IMC menunjukan angka yang tinggi, hal ini disebabkan bahwa harga memerlukan lebih dari 1 bulan periode untuk menyesuaikan. Hasil tersebut sesuai dengan penelitian Tahir dan Riaz (1997) yang menyatakan bahwa penyesuain harga pada komoditas pertanian umumnya memerlukan waktu, hal tersebut disebabkan oleh perbedaan intervensi pemerintah dalam pengelolaan pasca panen dan ancaman terhadap kekurangan pasokan bahan pangan.

Nilai koefisen $b_{2}$ pada lampiran 1 sebagai hasil regresi menunjukan bahwa dalam jangka panjang hampir semua provinsi acuan terintegrasi dengan provinsi lainya. Dari lampiran terlihat bahwa provinsi Jakarta dan Sulawesi Selatan merupakan provinsi yang terbukti signifikan terhadap daerah lainnya. Nilai $\mathrm{b}_{2}$ pada Jakarta sebagai acuan terlihat mendekati nilai 1 bahkan pada Riau memiliki nilai yang lebih dari $1(1,080)$ hal ini berarti apabila harga di Jakarta naik 1\% maka harga di Riau akan naik lebih dari 1,080 persen pada jangka panjang. Jarak 
yang dekat dengan daerah acuan akan memperlihatkan nilai yang baik hal ini terlihat dari Banten dimana nilai $\mathrm{b}_{2}$ sebesar 0,828 dengan Jawa Barat sebagai acuan, 0,840 dengan Jawa Tengah dan 0,949 dengan Jakarta memperlihatkan bahwa arus perdagangan diantara daerah tersebut menyebabkan adanya integrasi jangka panjang.

Sebagai daerah produsen yang surplus tidak semua daerah acuan memiliki arus perdagangan dengan daerah lainnya yang defisit, jarak ekonomis dapat dijadikan alasan kenapa daerah surplus tidak mau berdagang dengan daerah defisit. Hal ini dapat terlihat pada provinsi yang tidak terintegrasi dengan kedelapan provinsi acuan yaitu adalah NTT, Gorontalo, Kalimantan Tengah, Kalimantan Barat, Sulawesi Tengah, Maluku dan Maluku Utara. Jarak ekonomis yang jauh terhadap pasar acuan menyebabkan pasangan provinsi tersebut tidak terintegrasi dengan daerah yang dijadikan acuan dalam penelitian.

Yang menarik adalah provinsi Jawa Timur, sebagai daerah penghasil beras terbesar ke dua di Indonesia dengan total produksi mencapai 12,049 juta ton pada tahun 2013 tidak memperlihatkan nilai IMC maupun $b_{2}$ yang baik. Kedua nilai tersebut membuktikan bahwa Jawa Timur tidak tergintegrasi baik sebagai daerah acuan maupun daerah pengikut. Sebagai daerah acuan provinsi ini tidak terintegrasi dengan 32 provinsi lainnya, baik dalam jangka pendek maupun jangka panjang. Sedangkan sebagai pengikut Jawa Timur juga tidak terintegrasi dengan ke 7 provinsi acuan lainnya. Harga di Jawa Timur sebagai daerah yang tercukupi kebutuhan berasnya tidak terpengaruh oleh daerah acuan, Jawa Timur hanya dipengaruhi oleh harga pada periode sebelumnya. Sebagai daerah surplus, seharusnya Jawa Timur dapat menjadi daerah yang terintegrasi dengan berbagai daerah yang terkoneksi baik secara perdagangan maupun akses informasi. Sebagai daerah acuan pada periode penelitian Jawa Timur memiliki kegagalan pasar yakni dapat berupa kebijakan perdagangan ataupun rendahnya akses informasi yang tidak mendukung terjadinya pasar persaingan sempurna dengan daerah lainnya. Kelebihan supply yang terjadi di Jawa Timur tidak dengan baik disalurkan ke daerah kekurangan pasokan atau kelebihan demand.

Hasil integrasi jangka panjang memperlihatkan daerah mana yang terintegrasi dan tidak terintegrasi, Gambar 14 memperlihatkan bahwa komoditi beras memiliki daerah yang terintegrasi cukup luas. Dapat disimpulkan bahwa pulau Sumatera dan pulau Jawa dapat dengan baik menerima perubahan harga dari daerah acuan. Sedangkan pulau Kalimantan, Sulawesi dan Papua terlihat tidak terintegrasi dengan baik. Perubahan harga di daerah acuan tidak ditransmisiskan dengan baik oleh pulau-pulau tersebut.

Bila melihat baik nilai IMC maupun uji statistic $b_{2}$ yang melihat adanya integrasi baik jangka pendek maupun jangka panjang terlihat bahwa pada komoditi beras Jakarta dan Sulawesi Selatan merupakan daerah yang menjadi daerah acuan utama. Kedua daerah tersebut terintegrasi dengan sebagian besar wilayah di Indonesia, dan terbukti menjadi daeraha acuan bagi provinsi lainnya di Indonesia. Hal ini berbeda dengan hasil penelitiuan Bustaman (2013) dimana Jakarta, Jawa Barat dan Sumatera Utara merupakan provinsi acuan utama.

\section{Integrasi Jangka Pendek Pasar Gula di Indonesia}

Analisis integrasi pasar pada komoditi gula menggunakan 8 provinsi sebagai pasar acuan sedangkan provinsi lainnya sebagai pasar local yang mengacu harga terhadap pasar acuan. Nilai koefisien IMC dari yang disajikan pada Lampiran 1 
memperlihatkan bahwa integrasi jangka pendek secara umum terintegrasi diantara provinsi acuan dengan nilai mendekati nol. Integrasi secara kuat dalam jangka pendek terjadi pada pasangan Jawa Timur terhadap Lampung, Jawa Tengah terhadap Jawa Timur dan Lampung, serta Lampung terhadap Jawa Timur. Perubahan harga di ketiga daerah acuan ini saling berkaitan, akses informasi yang baik dari ketiga daeah produsen ini membuat konektifitas pasar diantara ketiganya berlangsung dengan baik.

Hubungan integrasi jangka pendek pada ketiga daerah produsen terbesar di Indonesia dapat disimpulkan terintegrasi secara kuat dalam jangka pendek. Nilai $b_{3}$ dalam lampiran 2 memperlihatkan bahwa nilai Jawa Timur terhadap Lampung sebesar 0,597, Jawa Tengah terhadap Jawa Timur sebesar 0,572, terhadap Lampung sebesar 0,509, nilai Lampung terhadap Jawa Timur sebesar 0,511. Angka $b_{3}$ ini menunjukan bahwa bila ada perubahan harga sebesar 1 rupiah di pasar acuan akan menyebabkan harga dari daerah produsen sebagai pengikut berubah sebesar nilai $b_{3}$ rupiah pada periode berikutnya. Atau apabila harga gula di Jawa Timur berubah sebesar 1 rupiah pada bulan sekarang maka Lampung akan berubah sebesar 0,597 rupiah pada bulan berikutnya.

Sebagai provinsi produsen gula tebu terbesar di Indonesia, Jawa Timur menjadi provinsi acuan dalam penentuan harga bagi provinsi produsen lainnya. Jawa Timur sebagai daerah produsen terbesar tebu yang memiliki luas areal tebu sebesar 69,57 persen pada tahun 2011 memiliki derajat integrasi jangka pendek yang baik dengan daerah lainnya. Sebagai pasar acuan daerah Jawa Timur, Jawa Tengah dan Lampung merupakan pasar acuan yang saling berkaitan. Nilai IMC yang kurang dari 1 memperlihatkan bahwa hubungan ketiga daerah ini terintegrasi secara kuat dalam jangka pendek. Nilai IMC Jawa Tengah terhadap Jawa Timur dan Lampung, nilai Jawa Timur terhadap Lampung, nilai Lampung terhadap Jawa Timur pada Lampiran 2 menunjukan angka kurang dari 1. Perubahan harga pada ketiga daerah acuan dan daerah produsen terbesar di Indonesia sangat berkaitan dalam jangka pendek.

Nilai IMC menunjukan derajat integrasi spasial diantara daerah yang diteliti, daerah acuan sebagai daerah produsen dan diasumsikan sebagai daerah yang surplus akan mempengaruhi harga di daerah yang defisit. Keterintegrasian harga jangka pendek disebut juga keterkaitan pasar dalam menjelaskan bagaimana para pelaku pemasaran berhasil menghubungkan pasar-pasar yang secara geografis terpisah melalui aliran informasi dan komoditi. Derajat integrasi yang kuat diperlihatkan dengan nilai IMC yang kurang dari 1 terlihat pada Jawa Timur terhadap Jambi, Kalimantan Barat, Banten dan Bangka Belitung. Provinsi Lampung terhadap Jambi, Sumatera Selatan, Bengkulu dan Bangka Belitung. Jawa Tengah terhadap Bengkulu, NTB, Bangka Belitung dan Sulawesi Barat. Jawa Barat terhadap Banten, Sumatera Utara terhadap Bengkulu dan NTB, Jakarta terhadap Bengkulu dan Bali, Kalimantan Selatan terhadap Aceh, Jambi, Sumatera Selatan, BengkuluNTB, Kalimantan Barat, Kalimantan Tengah dan Bangka Belitung, Gorontalo terhdap NTB dan Sulawesi Tengah.

Bila melihat IMC dimana nilainya kurang dari 1 dan terbukti terintegrasi dengan kuat terlihat bahwa jarak yang dekat dengan daerah acuan akan menghasilkan nilai IMC yang baik. Jarak yang dekat akan menyebabkan terjadinya proses perdagangan diantara keduanya dan memnyebabkan proses terjadinya harga akan lebih baik. Nilai IMC yang baik juga terdapat pada pasangan analisis yang memiliki jarak yang jauh dan tidak adanya proses perdagangan, hal ini bisa terjadi dengan adanya proses perolehan informasi 
yang baik sehingga pasar dapat menyesuaikan dengan kondisi di pasar acuan. Sebagai pasar pengikut yang mengacu terhadap pasar acuan, provinsi Kalimantan Timur, Sulawesi Tenggara, Papua, Sulawesi Barat, Papua Barat dan Kepulauan Riau merupakan provinsi yang tidak terintegrasi jangka pendek ataupun terintegrasi secara lemah dalam jangka pendek. Provinsi Kalimantan Timur terintegrasi secara lemah dengan provinsi Lampung, Jawa Tengah, Jawa Barat, Sulawesi Selatan, Jakarta dan Gorontalo sedangkan dengan provinsi Jawa Timur, Sumatera Utara dan Kalimantan Selatan tidak terintegrasi dalam jangka pendek.

Dalam Lampiran 2 dapat dilihat bahwa provinsi Papua tidak terintegrasi dalam jangka pendek dengan ke delapan provinsi acuan, dan hanya memiliki nilai IMC lebih dari 1 dan menunjukan integrasi yang sangat lemah dalam jangka pendek. Nilai IMC Papua terhadap Sumatera Utara sebagai provinsi acuan sebesar 3,739 adalah nilai yang paling mendekati nilai 1 . Provinsi Papua Barat juga menunjukan hasil tidak terintegrasi dalam jangka pendek nilai IMC yang dimana Jawa Timur sebagai provinsi acuan adalah nilai indeks yang terbaik yaitu 4,115. Provinsi Kepulauan Riau menunjukan nilai IMC lebih dari 1, keadaan ini menunjukan Kepulauan Riau tidak terintegrasi dalam jangka pendek dan hanya terintegrasi sangat lemah dengan provinsi acuan. Pangsa pasar yang kecil akan mengakibatkan lambatnya daerah tersebut dalam menyesuaikan harga dengan pasar acuan (Tahir dan Riaz, 1997)

Nilai IMC menunjukan derajat integrasi spasial diantara daerah yang diteliti, daerah acuan sebagai daerah produsen dan diasumsikan sebagai daerah yang surplus akan mempengaruhi harga di daerah yang defisit. Keterintegrasian harga jangka pendek disebut juga keterkaitan pasar dalam menjelaskan bagaimana para pelaku pemasaran berhasil menghubungkan pasar-pasar yang secara geografis terpisah melalui aliran informasi dan komoditi. Derajat integrasi yang kuat diperlihatkan dengan nilai IMC yang kurang dari 1 terlihat pada Jawa Timur terhadap Jambi, Bengkulu, Bali, dan Bangka Belitung; Jawa Tengah terhadap Bengkulu, Bali dan Bangka Belitung; Lampung terhadap Jambi, Bangka Belitung dan Sulawesi Tengah; Jawa Barat terhadap Banten; Jakarta terhadap Bali.

Bila melihat IMC Jawa Barat terhadap Banten dimana nilainya kurang dari 1 dan terbukti terintegrasi dengan kuat terlihat bahwa jarak yang dekat dengan daerah acuan akan menghasilkan nilai IMC yang baik. Jarak yang dekat akan menyebabkan terjadinya proses perdagangan diantara keduanya dan menyebabkan proses terjadinya harga akan lebih baik. Nilai IMC yang baik juga terdapat pada pasangan analisis yang memiliki jarak yang jauh dan tidak adanya proses perdagangan, hal ini bisa terjadi dengan adanya proses perolehan informasi yang baik sehingga pasar dapat menyesuaikan dengan kondisi di pasar acuan (Bustaman, 2003).

\section{Integrasi Jangka Panjang Pasar Gula di Indonesia}

Nilai koefisen $b_{2}$ pada Lampiran 2 sebagai hasil regresi menunjukan bahwa dalam jangka panjang provinsi acuan memiliki integrasi kuat terhadap pasar local adalah provinsi Jawa Tengah, Jawa Barat, Lampung dan Jakarta. Uji nilai statistic nilai $b_{2}$ pada provinsi Jawa Tengah sebagai pasar acuan menunjukan terintegrasi dalam jangka panjang dengan 8 provinsi lainnya pada taraf 5 persen. Lampung teintegrasi dengan 13 provinsi, Jawa Barat terintegrasi dengan 8 provinsi dan Jakarta terintegrasi dengan 28 provinsi lainnya di Indonesia. 


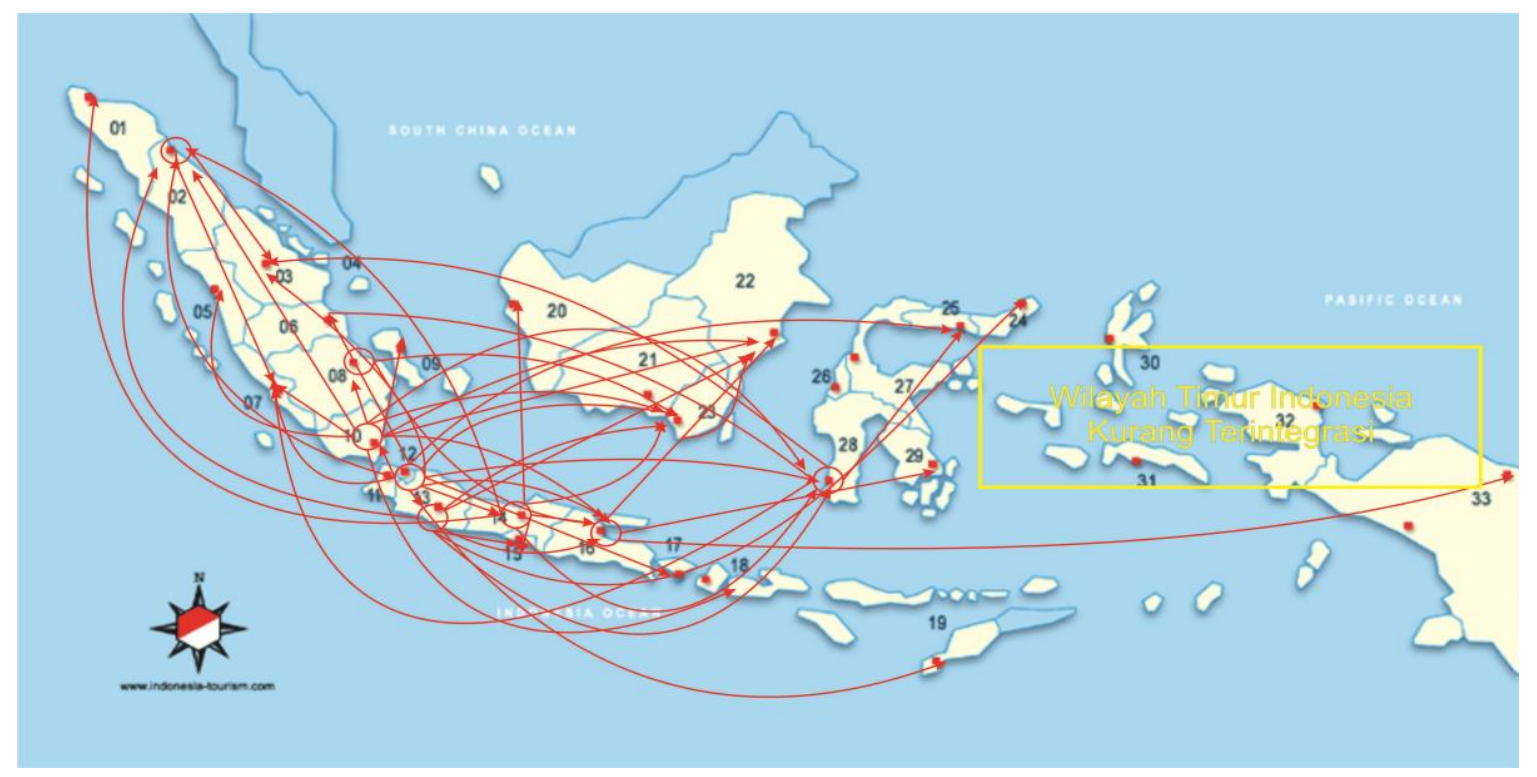

Gambar 3. Elastisitas Transmisi Harga Gula di 33 Provinsi di Indonesia

Jawa Timur merupakan provinsi gula terbesar di Indonesia dengan produksi gula 1,25 juta ton pada tahun 2013. Sebagai daerah acuan Jawa Timur hanya mempengaruhi pembentukan harga gula Kalimantan Selatan diperlihatkan dengan uji t-statistik $b_{2}$ yang menunjukan kedua pasangan tersebut terintegrasi dalam jangka panjang. Sebagai daerah pengikut Jawa Timur terintegrasi dengan lima daerah acuan ditunjukan dengan uji t-statistik $b_{2}$ yaitu Jawa Barat dengan nilai $(1,601)$, Jawa Tengah $(0,202)$, Sumatera Selatan $(1,959)$, Lampung $(0,955)$ dan Jakarta $(1,529)$ atau signifikan pada taraf 5 persen. Sedangkan transmisi harga terlihat pada nilai $b_{2}$ yaitu sebesar Jawa Barat dengan nilai $(0,82)$, Jawa Tengah $(0,987)$, Sumatera Selatan $(0,860)$, Lampung $(0,895)$ dan Jakarta $(0,980)$. Nilai b2 Jawa Timur ini terlihat bahwa perubahan harga di di daerah acuan dapat ditransmisikan dengan baik, sehingga para produsen gula di Jawa Timur dapat menikmati perubahan harga di daeerah konsumen gula.

Uji t-statistik $b_{2}$ pasar acuan Provinsi Jawa Tengah sebagai produsen gula tebu terbesar kedua di Indonesia menunjukan terintegrasi terhadap 8 provinsi lainnya. Nilai $b_{2}$ pada Jawa Timur menunjukan angka 0,987, nilai ini mendekati sempurna dimana perubahan harga di Jawa Timur sangat dipengaruhi oleh pergerakan harga di Jawa Tengah. Nilai $b_{2}$ Jawa Timur ini lebih tinggi dibandingkan Jakarta sebagai acuan, dimana angka $b_{2}$ menunjukan 0,980. Hal ini berarti bahwa sebagai daerah produsen terbesar di Indonesia, Jawa Timur terintegrasi dengan daerah acuan yaitu Jakarta dan Jawa Tengah sebagai daerah defisit gula. Petani di Jawa Timur dapat menikmati perubahan harga yang terjadi di daerah konsumen walau dalam jangka panjang.

Jawa Barat dengan potensi keempat sebagai produsen gula tebu nasional sebagai provinsi acuan memperlihatkan hasil terintegrasi dengan Jawa Timur, Sulawesi Selatan, Riau, Yogyakarta, Kalimantan Tengah, Kalimantan Selatan dan Kalimantan Timur dengan nilai $b_{2}$ mendekati 1 . Hal ini berarti bahwa perubahan harga di pasar Jawa Barat akan ditrasnformasikan secara selaras di pasar-pasar lainnya yang terintegrasi. Hubungan perdagangan antara provinsi tersebut menyebabkan kondisi pasar di pasar acuan akan terhubung dengan kondisi pasar pasar lainnya. Perubahan harga tersebut bisa berdasarkan hubungan perdagangan maupun apabila 
tidak terjadi perdagangan, integrasi pasar terjadi oleh karena kemudahan akses informasi.

Integrasi jangka panjang yang terdapat pada provinsi Jakarta sebagai daerah acuan, dalam uji t-statistik memperlihatkan bahwa semua provinsi terintegrasi kecuali NTT, Papua, Papua Barat dan Kepulauan Riau. Nilai uji $\mathrm{t}$-statistik $\mathrm{b}_{2}$ memperlihatkan integrasi terjadi pada 28 pasangan dengan angka signifikan 5 persen, nilai ini menunjukan bahwa Jakarta sebagai terbukti signifikan sebagai daerah acuan dalam pembentukan harga di hampir seluruh daerah di Indonesia untuk komoditi gula. Walaupun dalam jangka pendek yang dibuktikan nilai IMC Jakarta tidak berpengaruh dalam pembentukan harga, namun hal ini berbanding terbalik dimana Jakarta sebagai daerah defisit gula atau memperoleh gula dari daerah produsen lebih mempengaruhi proses pembentukan harga di provinsi lainnya dalam jangka panjang. Perbandingan Jakarta diuji sebagai daerah pengikut dan sebagai acuan memperlihatkan bahwa harga gula di Jakarta dalam jangka panjang lebih dipengaruhi oleh harga pada periode sebelumnya dan harga Jakarta lebih mempengaruhi harga di daerah lainnya. Jadi dalam jangka panjang proses stabilisasi harga gula nasional lebih efektif apabila harga gula di Jakarta stabil.

Pasar gula Indonesia yang saling terintegrasi dari seluruh provinsi yang ada hanya dapat terjadi apabila terdapat hubungan perdagangan maupun adanya akses informasi yang terkoneksi baik antar daerah. Jika terdapat kegagalan pasar maka efisiensi pemasaran dan informasi tidak terjadi sehingga integrasi antar daerah tidak akan efektif berlangsung. Integrasi jangka panjang pada produk gula menunjukan bahwa masih terdapat daerah atau provinsi yang tidak terhubung ataupun terintegrasi secara lemah. Pada Lampiran 2 dapat dilihat bahwa provinsi NTT,
Sulawesi Tenggara, Papua, Maluku Utara, Sulawesi Barat dan Papua Barat tidak terintegrasi dengan daerah acuan. Kelima provinsi tersebut setelah diuji statistic disimpulkan tidak terintegrasi dengan delapan provinsi acuan. Hasil uji integrasi jangka panjang dengan $b_{2}=1$ menunjukan bahwa tidak tolak hypothesis nol (Ho) yakni tidak terintegrasi dalam jangka panjang. Dapat dikatakan bahwa efisiensi pemasaran komoditi gula belum terjadi pada kelima provinsi tersebut, kurangnya akses informasi menyebabkan tidak terjadinya integrasi spasial (Firdaus dan Gunawan, 2012).

Transmisi harga gula di Indonesia pada Gambar 15 memperlihatkan bahwa wilayah Indonesia Bagian Timur merupakan wilayah yang kurang terintegrasi dengan daerah acuan. Perubahan harga di daerah acuan tidak ditrasnmisikan dengan baik ke daerah Papua, Sulawesi dan sebagian dari Kalimantan. Hubungan yang kurang baik antara daerah tersebut dengan pulau Jawa yang merupakan daerah konsumen terbesar di Indonesia dan daerah yang berpengaruh dalam pembentukan harga di Indonesia kurang diinformasikan ke daerah timur Indonesia. Hubungan perdagangan maupun akses dalam memperoleh informasi masih sangat rendah antara daerah acuan dengan daerah tersebut menyebabkan kurangnya tingkat terintegrasi. Transmisi harga yang terjadi pada Indonesia Bagian Timur sesuai dengan penelitian Issac dan Yeboah (2012) bahwa daerah dengan tingkat insfrastruktur yang kurang baik akan memperlihatkan tingkat integrasi yang rendah pula.

\section{Integrasi Jangka Pendek Pasar Kedelai di Indonesia}

Analisis integrasi pasar pada komoditi kedelai menggunakan 8 provinsi sebagai pasar acuan yaitu Jawa Barat, Jawa Timur, Jawa Tengah, Sulawesi Selatan, 
Sumateras Selatan, Lampung dan DKI Jakarta sedangkan provinsi lainnya sebagai pasar local yang mengacu harga terhadap pasar acuan. Hasil perhitungan menunjukan nilai IMC pada pasangan daerah Jawa Timur terhadap Jawa Tengah mempunyai nilai sebesar 1,001 angka ini mendekati angka 1 dimana dapat disimpulkan kedua daerah memiliki integrasi jangka pendek. Sedangkan nilai IMC untuk daerah yang lain memperlihatkan bahwa tidak terjadi integrasi jangka pendek pada komoditi kedelai pada delapan daerah acuan di Indonesia. Derajat integrasi pada Tabel 3 menunjukan hubungan antara delapan pasar acuan kedelai di Indonesia dengan duapuluh empat daerah lainnya. Hasil regresi memperlihatkan bahwa nilai IMC lebih dari 1 membuktikan bahwa harga kedelai tidak terintegrasi antara daerah acuan dan daerah lainnya.

Kedelai merupakan produk yang sangat penting untuk mencukupi kebutuhan protein nabati bagi penduduk di Indonesia, data BPS menyebutkan bahwa produksi kedelai di Indonesia mencapai angka 974512 ton pada tahun 2009 turun menjadi 779992 ton pada tahun 2013 sedangkan angka impor menunjukan 1314 619 ton pada tahun 2009 naik menjadi 1 785384 ton pada tahun 2013. Intervensi pasar oleh pemerintah dalam rangka stabilisasi harga dan pemenuhan permintaan pasar dalam negeri dilakukan dengan mengimpor lebih dari 70 persen kebutuhan kedelai.

Dari analisis integrasi spasial antar provinsi di Indonesia terlihat bahwa hubungan perdagangan kedelai antar daerah dapat dikatakan buruk, tataniaga kedelai dalam negeri terlihat belum berjalan dengan efektif. Integrasi pasar jangka pendek komoditi pertanian sangat jarang sekali terjadi, hal ini diseebabkan oleh perbedaan tingkat intervensi pemerintah, struktur permintaan dari daerah produsen, perbedaan teknologi pasca panen serta jarak antar pasar produsen dan konsumen yang menyebabkan perlunya waktu untuk mencapai kesetimbangan sehingga diperlukan waktu lebih dari sebulan untuk menyesuaikan (Tahir dan Riaz, 1997). Hal tersebut yang menyebabkan integrasi jangka pendek pada komoditi kedelai tidak terjadi dimana dari perhitungan nilai IMC mencapai lebih dari 1.

\section{Integrasi Jangka Panjang Pasar Kedelai di Indonesia}

Integrasi jangka panjang yang terjadi diantara daerah acuan kedelai di Indonesia dapat dilihat di Lampiran 3, memperlihatkan bahwa hanya terjadi integrasi di beberapa daerah yang diuji. Provinsi Jawa Timur dengan Jawa Tengah terbukti terintegrasi dalam jangka panjang dengan nilai $b_{2}$ sebesar 0,258 namun nilai $\mathrm{b}_{2}$ tidak signifikan sehingga dapat disimpulkan Jawa Timur tidak berpengaruh terhadap pembentukan harga di Jawa Tengah. Integrasi yang terjadi antara Jakarta dengan Jawa Tengah dengan nilai $\mathrm{b}_{2}$ mendekati angka 1 memperlihatkan bahwa perubahan harga di Jakarta akan ditransformasikan lebih baik oleh Jawa Tengah. Perubahan harga kedelai di Jakarta sebesar 1 persen pada jangka panjang akan ditransmisikan ke Jawa Tengah dengan perubahan harga sebesar 0,969 persen, dengan nilai yang mendekati 1 memperlihatkan bahwa transmisi harga di Jakarta dapat diserap dengan baik oleh Jawa Tengah sebagi provinsi produsen.

Uji t-stastistik nilai $b_{2}$ pada Lampiran 3, Lampung sebagai daerah acuan memperlihatkan terintegrasi dengan 9 daerah pengikut yaitu Jawa Barat, Sulawesi Utara, Sulawesi Tenggara, Bangka Belitung, Sulawesi Barat, Papua Barat dan Kepulauan Riau. Nilai $b_{2}$ pada Jawa Barat menunjukan angka 0,924 yaitu berarti bahwa dalam jangka panjang perubahan harga sebesar 1 persen di 
Lampung akan direspon oleh Jawa Barat sebesar 0,924 persen. Integrasi jangka panjang yang terjadi diantara produsen kedelai di Indonesia memperlihatkan bahwa hanya terjadi integrasi di beberapa daerah yang diuji. Integrasi pasar kedelai di Indonesia hanya terjadi di 11 provinsi di Indonesia, sedangkan 22 provinsi lainnya menunjukan nilai uji $\mathrm{t}$ yang tidak signifikan dan tidak terintegrasi dengan daerah acuan yang diteliti.

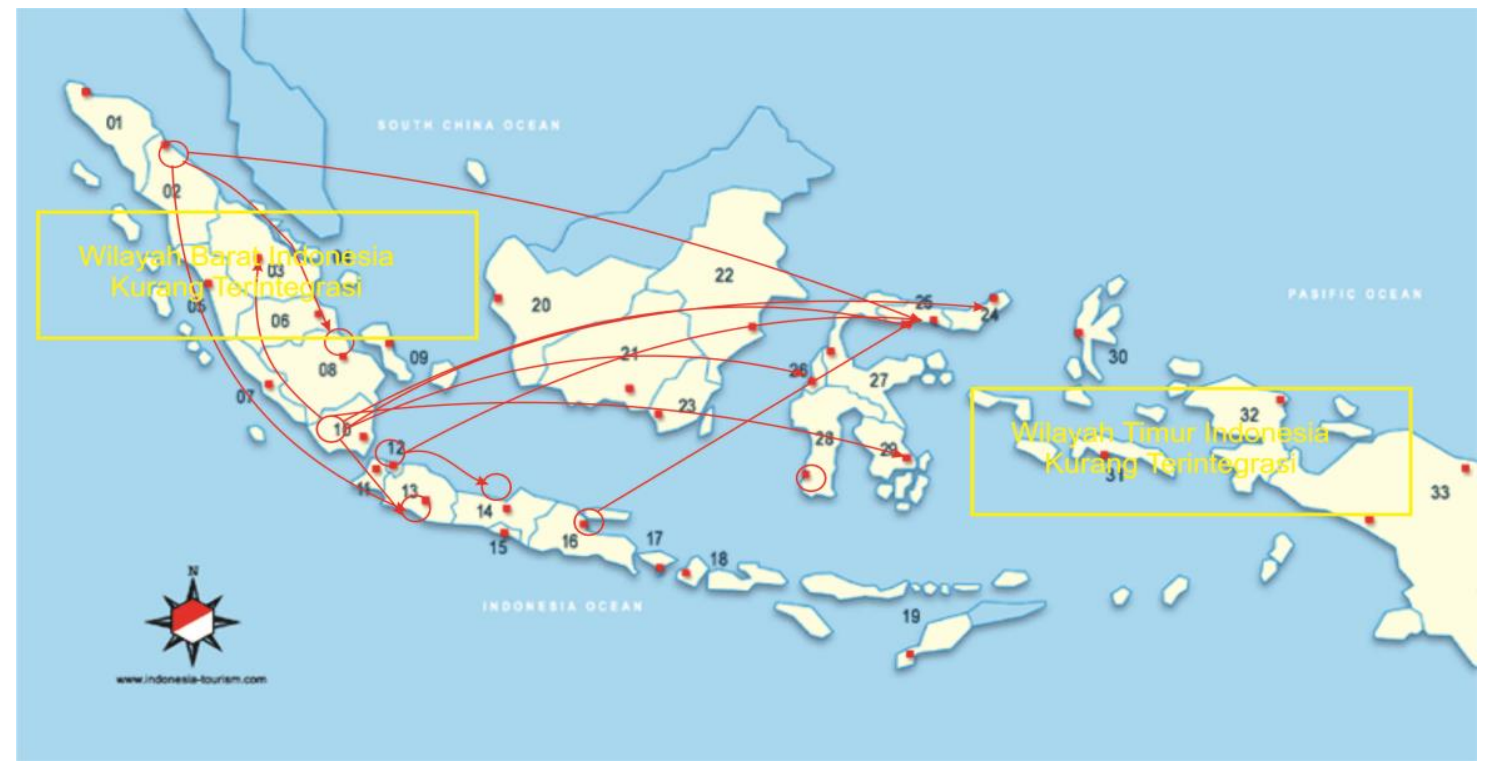

Gambar 4. Elastisitas Transmisi Harga Kedelai di 33 Provinsi di Indonesia

Besar tidaknya pangsa pasar dari suatu daerah akan mempengaruhi tingkat integrasi daerah tersebut dengan daerah produsen. Bila pangsa pasar suatu daerah itu kecil kemungkinan daerah tersebut akan terisolasi dengan daerah pasar besar ataupun daerah produsen akan semakin besar, demikian juga sebaliknya. Tataniaga kedelai di Indonesia terlihat dari analisis integrasi baik jangka pendek maupun panjang melalui nilai IMC maupun $b_{2}$ dapat disimpulkan bahwa tataniaga kedelai masih buruk. Kebijakan intervensi pasar yang dilakukan oleh pemerintah terbukti belum mampu menjalankan perdagangan secara efektif dan efisien. Persoalan ini disebabkan oleh adanya asymmetric information antar daerah, persoalan otonomi daerah yang memberlakukan berbagai rintangan dalam perdagangan ataupun dengan berkurangnya peran Bulog sebagai pengawas kebutuhan pasar sejak tahun 1998 membuat perdagangan antar daerah tidak terjadi dengan baik. Pasar persaingan sempurna yang diharapkan dengan memberi keleluasaan bagi pengusaha kedelai dalam tataniaga kedelai ternyata tidak terjadi, penawaran dari daerah produsen kepada daerah yang defisit tidak berlangsung dengan sempurna.

Integrasi spasial komoditi kedelai yang terjadi di 33 provinsi menunjukan bahwa terdapat beberapa wilayah Indonesia yang tidak terintegrasi secara baik. Analisis elastisitas transmisi harga yang ditunjukan oleh Gambar 4 memperlihatkan bahwa, Kalimantan, sebagian wilayah Sumatera dan sebagian dari Papua tidak terintegrasi dengan daerah acuan. Hanya terdapat 11 daerah yang terintegrasi dengan daerah acuan atau hanya 33 persen dari wilayah di Indonesia yang terhubung dalam pasar kedelai. Perubahan harga di pasar acuan tidak dengan baik ditransformasikan oleh wilayah-wilayah tersebut. Besar tidaknya pangsa pasar dari suatu daerah akan 
mempengaruhi tingkat integrasi daerah tersebut dengan daerah produsen. Bila pangsa pasar suatu daerah itu kecil kemungkinan daerah tersebut akan terisolasi dengan daerah pasar besar ataupun daerah produsen akan semakin besar, demikian juga sebaliknya.

Kedelai merupakan komoditi yang sangat penting di Indonesia sebagai protein nabati utama dalam produk pangan di Indonesia. Permintaan yang tinggi dan produksi yang masih sedikit menyebabkan Indonesia masih mengimpor produk ini dalam mencukupi kebutuhan dalam negeri. Efisiensi perdagangan komoditi kedelai masih berjalan dengan tidak efektif, pangsa pasar bagi wilayah Indonesia timur yang relative kecil mengakibatkan lambatnya daerah tersebut dalam menyesuaikan harga dengan pasar acuan (Tahir dan Riaz, 1997).

Elastisitas transmisi harga kedelai di Indonesia pada Gambar 4 memperlihatkan bahwa wilayah Indonesia Bagian Timur dan Indonesia Bagian Barat merupakan wilayah yang kurang terintegrasi dengan daerah acuan. Perubahan harga di daerah acuan tidak ditransmisikan dengan baik ke pulau Sumatera, Papua, Kalimantan dan sebagian Sulawesi. Hubungan perdagangan komoditi kedelai belum berjalan dengan efektif menyebabkan tidak terdapat cukup bukti yang memperlihatkan suatu daerah menjadi pasar acuan. Proses pembentukan harga kedelai lebih dipengaruhi oleh factor-faktor lokal yang terdapat di daerah tersebut (Bustaman, 2003)

\section{KESIMPULAN}

1. Hasil perhitungan IMC (Index of Market Connection) komoditi pangan menunjukan bahwa integrasi spasial antar provinsi jangka pendek hanya terjadi pada komoditi gula. Nilai IMC yang kurang dari satu memperlihatkan bahwa harga gula antar provinsi pada jangka pendek sangat berkaitan, struktur pasar dan efisiensi perdagangan komoditi antar provinsi tersebut telah terbentuk dengan baik.

2. Nilai b2 yang diuji secara statistic menunjukan bahwa komoditi beras, gula, telah terintegrasi jangka panjang dengan baik. Struktur pasar, efisiensi perdagangan dan akses informasi antar provinsi telah berlangsung dengan baik sehingga menyebabkan integrasi pasar jangka panjang terjadi pada keempat komoditi tersebut. Sedangkan untuk komoditi kedelai, tingkat integrasi spasial antar provinsi menunjukan proses integrasi belum berjalan dengan baik.

3. Analisis integrasi spasial antar provinsi menggunakan nilai IMC dan b2 sebagai indikator menunjukan bahwa pasar komoditi pangan memiliki beberapa daerah yang dijadikan acuan. Pada komoditi beras dapat disimpulkan bahwa Jakarta dan Sulawesi Selatan merupakan daerah yang menjadi daerah acuan utama, daerah tersebut terintegrasi dengan sebagian besar wilayah di Indonesia. Untuk komoditi gula, daerah yang menjadi provinsi acuan utama adalah Jakarta. Sedangkan untuk komoditi kedelai tidak terdapat daerah yang dijadikan daerah acuan utama.

4. Tingkat integrasi spasial dari komoditi beras dan gula, daging ayam dan daging sapi di Indonesia mendekati pasar persaingan sempurna (competitive market) dibandingkan tingkat integrasi kedelai.

5. Besaran nilai b2 sebagai indikator elastisitas transmisi harga dan integrasi menunjukan bahwa perubahan harga di provinsi acuan dapat dengan baik ditransmisikan ke sebagian besar provinsi lainnya di Indonesia namun perubahan harga di provinsi acuan tidak ditransmisikan dengan baik kedaerah Indonesia Bagian Timur. 


\section{SARAN}

1. Sebagai daerah yang dijadikan acuan terhadap pangan di pasar-pasar lainnya, perubahan harga di Jakarta akan ditransmisikan secara selaras pada daerah lainnya. Oleh karena itu dalam rangka stabilisasi harga di Indonesia, provinsi tersebut harus dijaga dengan baik sehingga lebih efektif dan efisien dalam menahan gejolak harga sehingga tidak meluas ke daerah lainnya. Implementasi kebijakan pemerintah pusat dalam menstabilisasi harga lebih baik diarahkan ke daerah acuan tersebut sehingga biaya yang dikeluarkan dapat lebih murah.

2. Jawa Timur merupakan provinsi produsen bahan pangan nomer satu Indonesia baik beras dan kedelai maupun gula dimana daerah ini merupakan daerah surplus bahan pangan diharapkan dapat terintegrasi secara baik dengan daerah lainnya di Indonesia. Namun setelah dianalisis nilai IMC maupun $b_{2}$ sebagai koefisien integrasi terbukti bahwa Jawa Timur tidak secara baik terintegrasi dengan daerah lainnya. Analisis integrasi model Ravallion tidak dapat menjelaskan apa yang menjadi penyebab terjadinya integrasi, sehingga diperlukan kajian lebih lanjut terhadap provinsi Jawa Timur baik dari segi kebijakan perdagangan ataupun adanya market failure yang terjadi sehingga dapat menemukan solusi kebijakan agar integrasi dapat terjadi dengan lebih baik.

3. Diperlukan kebijakan pemerintah dalam efisiensi tataniaga kedelai untuk meningkatkan integrasi spasial antar provinsi yang masih rendah dimana kedelai merupakan komoditi yang diperlukan oleh seluruh lapisan masyarakat di Indonesia.

\section{DAFTAR PUSTAKA}

Issac I, Yeboah. 2013. Spatial Price Transmission in The Regional Maize Market in Ghana.. University of Bonn. Swedish. Munich Personal Repec Archive No.49720:

[BAPOKSTRA] Direktorat Bahan Pokok dan Barang Strategis. Ditjen Perdagangan Dalam Negeri Kementerian Perdagangan. 2014. Harga Bahan Pokok. Jakarta : Kemendag.

[BPS] Badan Pusat Statistik. 2014. Statistik Indonesia. Jakarta: BPS.

Bustaman A. 2003. Analisis Integrasi Pasar Beras di Indonesia. [skripsi]. Bogor (ID): Institut Pertanian Bogor.

Firdaus M, Gunawan I. 2012. Integration Among Regional Vegetable Market in Indonesia. Journal ISSAAS. 18 (2):96-106

Fackler P, Goodwin BK. 2001. Handbook of Agricultural Economics, Vol 1. Department of Agricultural \& Resource Economics, North Carolina State University, Raleigh, NC

Heytens PJ. 1986. Testing Market Integration. Food Research Institute Studies. XX (1): 25-41.

[IMF] International Monetary Fund. 2014. IMF Primary Comodity Prices. http://www.imf.org/external/np/res/c ommod/index.aspx.

[Kemenko Ekon] Kementerian Koordinator Bidang Perekonomian. 2010. Peraturan Menteri Koordinator Bidang Perekonomian No. 28 Tahun 2010 tentang Tim Koordinasi Stabilisasi Pangan Pokok. Jakarta (ID): Kemenko Ekon.

Ravallion, M. 1986. Testing Market Integration. American Journal of Agricultural Economics. 68 (1):101-108.

Tahir Z. Riaz K. 1997. Integration of Agricultural Commodity Markets in Punjab. The Pakistan Development Review. 36 (3): 241-262. 
Timmer PC. 1986. Getting Prices Right The Scope and Limits of Agricultural Price Policy. Ithaca, NY: Cornell University Press

Tomek W. Robinson KL. 1990. Agricultural Product Prices. Third
Edition. Cornell University Press. Ithaca.

Pemerintah Republik Indonesia. 2014. Undang-undang Negara Republik Indonesia Nomor 7 Tahun 2014 tentang Perdagangan. Jakarta (ID): Sekretariat Negara. 
Lampiran 1. Hasil Pendugaan Regresi Model Ravalion Komoditi Beras di Indonesia

\begin{tabular}{|c|c|c|c|c|c|c|c|c|c|c|c|c|c|c|c|c|c|c|c|c|}
\hline \multirow{2}{*}{$\begin{array}{l}\text { Provinsi Acuan } \\
\text { Provinsi Pengikut }\end{array}$} & \multicolumn{5}{|c|}{ Jawa Barat } & \multicolumn{5}{|c|}{ Jawa Timur } & \multicolumn{5}{|c|}{ Jawa Tengah } & \multicolumn{5}{|c|}{ Sulawesi Selatan } \\
\hline & $b_{1}$ & $\mathrm{~b}_{2}$ & $\mathrm{~b}_{3}$ & IMC & $b_{2}-1$ & $\mathrm{~b}_{1}$ & $\mathrm{~b}_{2}$ & $b_{3}$ & IMC & $b_{2}-1$ & $\mathrm{~b}_{1}$ & $\mathrm{~b}_{2}$ & $b_{3}$ & IMC & $b_{2}-1$ & $b_{1}$ & $\mathrm{~b}_{2}$ & $b_{3}$ & IMC & $b_{2}-1$ \\
\hline Jawa Barat & & & & & & $0.876 \mathrm{a} C$ & a 0.358 a & $0.134 b$ & 6.55 & $0.642^{\mathrm{d}}$ & $0.730 \mathrm{a} 0$ & $0.768 \mathrm{a}$ & $0.283 a$ & 2.58 & $0.232^{\mathrm{d}}$ & d $0.832 \mathrm{a}$ & a 0.924 a & $0.203 \mathrm{c}$ & 4.09 & 0.076 \\
\hline Jawa Timur & $0.925 \mathrm{a} 0$ & $0.344 a$ & 0.072 & 12.77 & $-0.656^{c}$ & & & & & & $0.900 \mathrm{a} 0$ & $0.510 \mathrm{a}$ & 0.100 & 9.04 & $0.490^{\mathrm{d}}$ & d $0.985 a$ & a 0.210 & 0.019 & 52.15 & $0.790^{c}$ \\
\hline Jawa Tengah & $0.877 \mathrm{a} 0$ & $0.738 \mathrm{a}$ & 0.118 & 7.41 & -0.262 & $0.842 \mathrm{a}$ & a $0.424 a$ & $0.161 \mathrm{~b}$ & 5.25 & $0.576^{\mathrm{d}}$ & & & & & & $0.935 \mathrm{a}$ & a $0.736 a$ & 0.075 & 12.46 & 0.264 \\
\hline Sulawesi Selatan & $0.830 \mathrm{a} 0$ & $0.268 \mathrm{a}$ & $0.143 \mathrm{a}$ & 5.80 & -0.732 & $0.920 \mathrm{a}$ & a 0.067 & $0.073 \mathrm{a}$ & 12.59 & $0.933^{\mathrm{d}}$ & $0.824 \mathrm{a} 0$ & $0.222 \mathrm{a}$ & $0.156 a$ & 5.29 & $0.778^{d}$ & & & & & \\
\hline Sumatera Utara & $0.777 \mathrm{a} 0$ & $0.477 \mathrm{a}$ & $0.230 \mathrm{a}$ & 3.38 & $-0.523^{c}$ & $0.735 \mathrm{a}$ & a 0.268 & $0.288 \mathrm{a}$ & 2.55 & $0.732^{\mathrm{d}}$ & $0.737 \mathrm{a}$ & 0.285 & $0.283 \mathrm{a}$ & 2.61 & $0.715^{\mathrm{d}}$ & d $0.823 a$ & a $0.802 \mathrm{a}$ & $0.218 \mathrm{a}$ & 3.77 & 0.198 \\
\hline Sumatera Selatan & $0.927 \mathrm{a} 0$ & $0.583 \mathrm{a}$ & 0.068 & 13.64 & $-0.417^{c}$ & $0.931 \mathrm{a}$ & a 0.001 & 0.070 & 13.21 & $0.999^{\mathrm{d}}$ & $0.938 \mathrm{a} 0$ & $0.645 \mathrm{a}$ & 0.062 & 15.24 & $0.355^{\mathrm{d}}$ & d $0.858 \mathrm{a}$ & a $0.870 \mathrm{a}$ & 0.156 & 5.50 & 0.130 \\
\hline Lampung & $0.906 \mathrm{a} 0$ & $0.319 \mathrm{a}$ & 0.081 & 11.15 & $-0.681^{c}$ & $0.839 \mathrm{a} C$ & a $0.309 b$ & $0.148 \mathrm{~b}$ & 5.67 & $0.691^{\mathrm{d}}$ & $0.894 \mathrm{a} 0$ & $0.303 \mathrm{~b}$ & $0.097 \mathrm{c}$ & 9.26 & $0.697^{\mathrm{d}}$ & d $0.964 \mathrm{a}$ & a $0.500 \mathrm{~b}$ & 0.035 & 27.40 & $0.500^{\mathrm{c}}$ \\
\hline Jakarta & $0.773 \mathrm{a} 0$ & $0.523 \mathrm{a}$ & $0.235 \mathrm{a}$ & 3.29 & -0.477 & $0.902 \mathrm{a} C$ & $0.234 \mathrm{~b}$ & $0.109 b$ & 8.28 & $0.766^{\mathrm{d}}$ & $0.830 \mathrm{a} 0$ & $0.465 \mathrm{a}$ & $0.184 a$ & 4.51 & $0.535^{\mathrm{d}}$ & d $0.895 \mathrm{a}$ & a 0.857 a & $0.132 \mathrm{a}$ & 6.80 & 0.143 \\
\hline Sumatera Barat & $0.958 \mathrm{a} 0$ & $0.584 \mathrm{a}$ & 0.045 & 21.11 & $-0.416^{\prime}$ & $0.934 \mathrm{a}$ & 0.286 & 0.079 & 11.88 & $0.714^{\mathrm{d}}$ & $0.951 \mathrm{a} 0$ & $0.385 \mathrm{a}$ & 0.058 & 16.45 & $0.615^{\mathrm{d}}$ & d $0.968 \mathrm{a}$ & $0.635 \mathrm{c}$ & $=0.040$ & 24.07 & 0.365 \\
\hline $\begin{array}{l}\text { Kalimantan } \\
\text { Selatan }\end{array}$ & $0.936 \mathrm{a}$ & 0.092 & 0.058 & 16.05 & $-0.908^{c}$ & $0.962 \mathrm{a}$ & -0.373 & 0.037 & 26.23 & $1.373^{\mathrm{d}}$ & $0.939 \mathrm{a}$ & 0.027 & 0.059 & 15.90 & $0.973^{\mathrm{d}}$ & d $0.925 \mathrm{a}$ & a 0.114 & 0.085 & 10.91 & 0.886 \\
\hline Aceh & $0.797 \mathrm{a} 0$ & $0.640 \mathrm{a}$ & $0.210 \mathrm{a}$ & 3.79 & $-0.360^{c}$ & $0.878 \mathrm{a}$ & 0.068 & $0.136 \mathrm{~b}$ & 6.43 & $0.932^{\mathrm{d}}$ & $0.817 \mathrm{a} 0$ & $0.400 \mathrm{c}$ & $0.199 a$ & 4.10 & $0.600^{\mathrm{d}}$ & d $0.767 \mathrm{a}$ & a $0.574 b$ & $0.291 \mathrm{a}$ & 2.64 & 0.426 \\
\hline Riau & $0.753 \mathrm{a} 0$ & $0.582 \mathrm{c}$ & $0.279 \mathrm{a}$ & 2.70 & -0.418 & $0.612 \mathrm{a}$ & 0.112 & $0.465 \mathrm{a}$ & 1.32 & $0.888^{\mathrm{d}}$ & $0.723 \mathrm{a}$ & 0.076 & $0.330 \mathrm{a}$ & 2.19 & $0.924^{\mathrm{d}}$ & d $0.805 a$ & a 0.575 & $0.266 \mathrm{~b}$ & 3.03 & 0.425 \\
\hline Jambi & $0.727 \mathrm{a} 0$ & $0.353 \mathrm{~b}$ & $0.288 \mathrm{a}$ & 2.53 & -0.647 & $0.766 \mathrm{a} C$ & $0.451 \mathrm{a}$ & $0.260 \mathrm{a}$ & 2.95 & $0.549^{\mathrm{d}}$ & $0.663 \mathrm{a} 0$ & $0.467 \mathrm{a}$ & $0.369 a$ & 1.80 & $0.533^{\mathrm{d}}$ & d $0.882 \mathrm{a}$ & $0.817 \mathrm{a}$ & 0.150 & 5.87 & 0.183 \\
\hline Bengkulu & $0.803 \mathrm{a} 0$ & $0.597 \mathrm{a}$ & $0.178 \mathrm{~b}$ & 4.51 & $-0.403^{\prime}$ & $0.835 \mathrm{a} C$ & $0.414 \mathrm{~b}$ & $0.157 b$ & 5.32 & $0.586^{\mathrm{d}}$ & $0.749 \mathrm{a} 0$ & $0.706 \mathrm{a}$ & $0.237 \mathrm{a}$ & 3.16 & 0.294 & $0.793 a$ & $0.960 \mathrm{a}$ & $0.224 b$ & 3.54 & 0.040 \\
\hline Yogyakarta & $0.813 \mathrm{a} 0$ & $0.717 \mathrm{a}$ & $0.167 \mathrm{~b}$ & 4.87 & $-0.283^{\prime}$ & $0.835 \mathrm{a} C$ & $0.584 a$ & $0.156 \mathrm{~b}$ & 5.36 & $0.416^{\mathrm{d}}$ & $0.680 \mathrm{a} 0$ & $0.996 \mathrm{a}$ & $0.299 a$ & 2.27 & 0.004 & $0.849 \mathrm{a}$ & a $0.908 \mathrm{a}$ & $0.162 \mathrm{c}$ & 5.25 & 0.092 \\
\hline Bali & $0.909 \mathrm{a} 0$ & $0.393 a$ & 0.087 & 10.50 & -0.607 & $0.842 \mathrm{a}$ & $0.277 \mathrm{a}$ & $0.159 a$ & 5.29 & $0.723^{\mathrm{d}}$ & $0.865 \mathrm{a} 0$ & $0.590 \mathrm{a}$ & $0.134 \mathrm{~b}$ & 6.45 & $0.410^{\mathrm{d}}$ & d $0.906 \mathrm{a}$ & a $0.937 \mathrm{a}$ & 0.106 & 8.57 & 0.063 \\
\hline NTB & $0.854 \mathrm{a} 0$ & $0.440 \mathrm{a}$ & $0.118 \mathrm{c}$ & 7.24 & $-0.560^{\prime}$ & $0.862 \mathrm{a} C$ & $0.095 \mathrm{~b}$ & $0.119 b$ & 7.25 & $0.905^{\mathrm{d}}$ & $0.804 \mathrm{a} 0$ & $0.473 a$ & $0.166 \mathrm{~b}$ & 4.86 & $0.527^{\mathrm{d}}$ & d $0.692 a$ & $1.312 \mathrm{a}$ & $0.297 a$ & 2.33 & -0.312 \\
\hline NTT & $0.973 \mathrm{a}$ & 0.111 & 0.023 & 42.69 & $-0.889^{\prime}$ & $0.965 \mathrm{a}$ & 0.005 & 0.031 & 30.76 & $0.995^{\mathrm{d}}$ & $0.968 \mathrm{a}$ & 0.190 & 0.028 & 34.86 & $0.810^{\mathrm{d}}$ & d $0.962 \mathrm{a}$ & a $0.430 \mathrm{a}$ & 0.038 & 25.59 & $0.570^{c}$ \\
\hline Gorontalo & $0.932 \mathrm{a}$ & 0.084 & 0.055 & 17.06 & $-0.916^{\prime}$ & 0.899a & 0.135 & 0.086 & 10.49 & $0.865^{\mathrm{d}}$ & $0.929 \mathrm{a}$ & 0.258 & 0.059 & 15.62 & $0.742^{\mathrm{d}}$ & d 0.935 & $0.005 \mathrm{a}$ & 0.063 & 14.73 & $0.995^{i}$ \\
\hline Kalimantan Barat & $0.943 \mathrm{a} 0$ & $0.154 \mathrm{~b}$ & 0.063 & 15.07 & $-0.846^{\prime}$ & $0.929 \mathrm{a} \mathrm{C}$ & $0.094 \mathrm{c}$ & $0.082 a$ & 11.39 & $0.906^{\mathrm{d}}$ & $0.918 \mathrm{a} 0$ & $0.197 \mathrm{~b}$ & $0.093 b$ & 9.92 & $0.803^{\mathrm{d}}$ & d $0.978 \mathrm{~b}$ & $0.282 a$ & $0.029 \mathrm{a}$ & 33.58 & $0.718^{i}$ \\
\hline $\begin{array}{l}\text { Kalimantan } \\
\text { Tengah }\end{array}$ & $0.934 a-$ & -0.080 & 0.063 & 14.84 & $1.080^{\mathrm{d}}$ & $0.830 \mathrm{a}$ & $0.021 \mathrm{a}$ & $0.163 \mathrm{a}$ & 5.09 & $0.979^{\mathrm{d}}$ & $0.944 \mathrm{a}$ & 0.020 & $0.055 \mathrm{a}$ & 17.06 & $0.980^{\mathrm{d}}$ & d 0.937 & 0.124 & $0.071 \mathrm{a}$ & 13.19 & $0.876^{\mathrm{c}}$ \\
\hline Kalimantan Timur & $0.750 \mathrm{a} 0$ & $0.231 \mathrm{a}$ & $0.247 \mathrm{a}$ & 3.04 & $0.769^{d}$ & $0.868 \mathrm{a}$ & $0.149 \mathrm{a}$ & $0.139 a$ & 6.26 & $0.851^{\mathrm{d}}$ & $0.696 \mathrm{a}$ & 0.039 & $0.313 \mathrm{a}$ & 2.22 & $0.961^{\mathrm{d}}$ & d $0.831 \mathrm{a}$ & $0.704 \mathrm{~b}$ & $0.200 \mathrm{a}$ & 4.15 & 0.296 \\
\hline Sulawesi Utara & $0.821 \mathrm{a} 0$ & $0.431 \mathrm{a}$ & $0.181 \mathrm{a}$ & 4.53 & $0.569^{\mathrm{d}}$ & $0.816 \mathrm{a}$ & $0.138 a$ & $0.197 \mathrm{a}$ & 4.15 & $0.862^{\mathrm{d}}$ & $0.702 \mathrm{a} 0$ & $0.329 \mathrm{a}$ & $0.315 \mathrm{a}$ & 2.23 & $0.671^{\mathrm{d}}$ & d $0.831 \mathrm{a}$ & a $0.832 a$ & $0.205 b$ & 4.06 & 0.168 \\
\hline Sulawesi Tengah & $0.720 \mathrm{a} 0$ & $0.224 \mathrm{~b}$ & $0.261 \mathrm{a}$ & 2.76 & $0.776^{\mathrm{d}}$ & $0.782 \mathrm{a}$ & $0.038 \mathrm{a}$ & $0.215 \mathrm{a}$ & 3.63 & $0.962^{\mathrm{d}}$ & $0.678 \mathrm{a}$ & 0.006 & $0.315 \mathrm{a}$ & 2.15 & $0.994^{\mathrm{d}}$ & d $0.817 \mathrm{a}$ & 0.183 & $0.207 \mathrm{~b}$ & 3.94 & $0.817^{\mathrm{c}}$ \\
\hline $\begin{array}{l}\text { Sulawesi } \\
\text { Tenggara }\end{array}$ & $0.845 \mathrm{a}$ & 0.156 & $0.129 \mathrm{a}$ & 6.53 & $0.844^{\mathrm{d}}$ & $0.876 \mathrm{a}$ & $0.100 \mathrm{a}$ & $0.110 \mathrm{a}$ & 7.98 & $0.900^{\mathrm{d}}$ & $0.796 \mathrm{a}-$ & -0.002 & $0.178 \mathrm{a}$ & 4.46 & $1.002^{\mathrm{d}}$ & d $0.847 \mathrm{a}$ & $\mathrm{a} 0.541 \mathrm{~b}$ & $0.153 b$ & 5.52 & 0.459 \\
\hline Maluku & $0.975 \mathrm{a}$ & 0.080 & 0.020 & 48.70 & $0.920^{\mathrm{d}}$ & $0.939 \mathrm{a}$ & $0.043 \mathrm{c}$ & $0.053 \mathrm{c}$ & 17.86 & $0.957^{\mathrm{d}}$ & $0.968 \mathrm{a} 0$ & $0.176 \mathrm{c}$ & 0.027 & 35.84 & $0.824^{\mathrm{d}}$ & d $0.973 a$ & 0.193 & 0.026 & 37.96 & $0.807^{c}$ \\
\hline Papua & $0.943 a-$ & -0.148 & 0.070 & 13.45 & $1.148^{\mathrm{d}}$ & $0.951 \mathrm{a}$ & -0.322 & 0.066 & 14.43 & $1.322^{\mathrm{d}}$ & $0.950 \mathrm{a}-$ & -0.278 & 0.066 & 14.40 & $1.278^{\mathrm{d}}$ & d $0.940 \mathrm{a}$ & 0.560 & 0.086 & 10.90 & $0.440^{c}$ \\
\hline Banten & $0.676 \mathrm{a} 0$ & $0.828 \mathrm{a}$ & $0.305 \mathrm{a}$ & 2.22 & $0.172^{\mathrm{d}}$ & $0.860 \mathrm{a}$ & $0.412 b$ & $0.141 \mathrm{~b}$ & 6.09 & $0.588^{\mathrm{d}}$ & $0.786 \mathrm{a} 0$ & $0.840 \mathrm{a}$ & $0.211 \mathrm{a}$ & 3.72 & 0.160 & $0.797 a$ & $1.199 \mathrm{a}$ & $0.230 \mathrm{a}$ & 3.47 & -0.199 \\
\hline Bangka Belitung & $0.527 \mathrm{a} 0$ & $0.516 \mathrm{a}$ & $0.519 \mathrm{a}$ & 1.01 & $0.484^{\mathrm{d}}$ & $0.893 \mathrm{a}$ & $0.320 \mathrm{~b}$ & $0.126 \mathrm{c}$ & 7.07 & $0.680^{\mathrm{d}}$ & $0.645 \mathrm{a} 0$ & $0.486 a$ & $0.408 \mathrm{a}$ & 1.58 & $0.514^{\mathrm{d}}$ & $\mathrm{d} 0.819 \mathrm{a}$ & $0.758 \mathrm{a}$ & $0.240 \mathrm{~b}$ & 3.41 & 0.242 \\
\hline Maluku Utara & $0.927 \mathrm{a}$ & 0.093 & 0.075 & 12.35 & $0.907^{\mathrm{d}}$ & $0.909 \mathrm{a}$ & $0.120 \mathrm{c}$ & 0.098 & 9.31 & $0.880^{\mathrm{d}}$ & $0.939 \mathrm{a}$ & 0.077 & 0.065 & 14.36 & $0.923^{\mathrm{d}}$ & d $0.959 \mathrm{a}$ & 0.031 & 0.052 & 18.38 & $0.969^{\mathrm{c}}$ \\
\hline Sulawesi Barat & $0.930 \mathrm{a}$ & 0.164 & 0.067 & 13.88 & $0.836^{\mathrm{d}}$ & $0.848 \mathrm{a}$ & $0.002 \mathrm{a}$ & 0.153 & 5.54 & $0.998^{\mathrm{d}}$ & $0.892 \mathrm{a}$ & 0.170 & 0.108 & 8.26 & $0.830^{\mathrm{d}}$ & d $0.934 \mathrm{a}$ & $0.609 \mathrm{~b}$ & 0.074 & 12.60 & 0.391 \\
\hline Papua Barat & $0.908 \mathrm{a}$ & 0.044 & 0.102 & 8.88 & $0.956^{\mathrm{d}}$ & $0.892 \mathrm{a}-$ & $-0.180 \mathrm{t}$ & 0.127 & 7.02 & $1.180^{\mathrm{d}}$ & $0.905 \mathrm{a}$ & 0.017 & 0.111 & 8.16 & $0.983^{\mathrm{d}}$ & d $0.941 \mathrm{a}$ & 0.145 & 0.079 & 11.84 & $0.855^{c}$ \\
\hline Kepulauan Riau & $0.958 \mathrm{a} 0$ & $0.546 \mathrm{a}$ & 0.034 & 28.13 & $0.454^{\mathrm{d}}$ & $0.941 \mathrm{a}$ & 0.164 & 0.055 & 17.18 & $0.836^{\mathrm{d}}$ & $0.949 \mathrm{a} 0$ & $0.528 \mathrm{a}$ & 0.045 & 21.05 & $0.472^{\mathrm{d}}$ & d $0.956 \mathrm{a}$ & $0.819 a$ & 0.042 & 22.80 & 0.181 \\
\hline
\end{tabular}

a nyata pada taraf $1 \%$

b nyata pada taraf $5 \%$

c nyata pada taraf $10 \%$
d nyata pada taraf $5 \%$ (uji t-statistik dari t-table $=1.96$ ) $/$ pasar tidak terintegrasi 


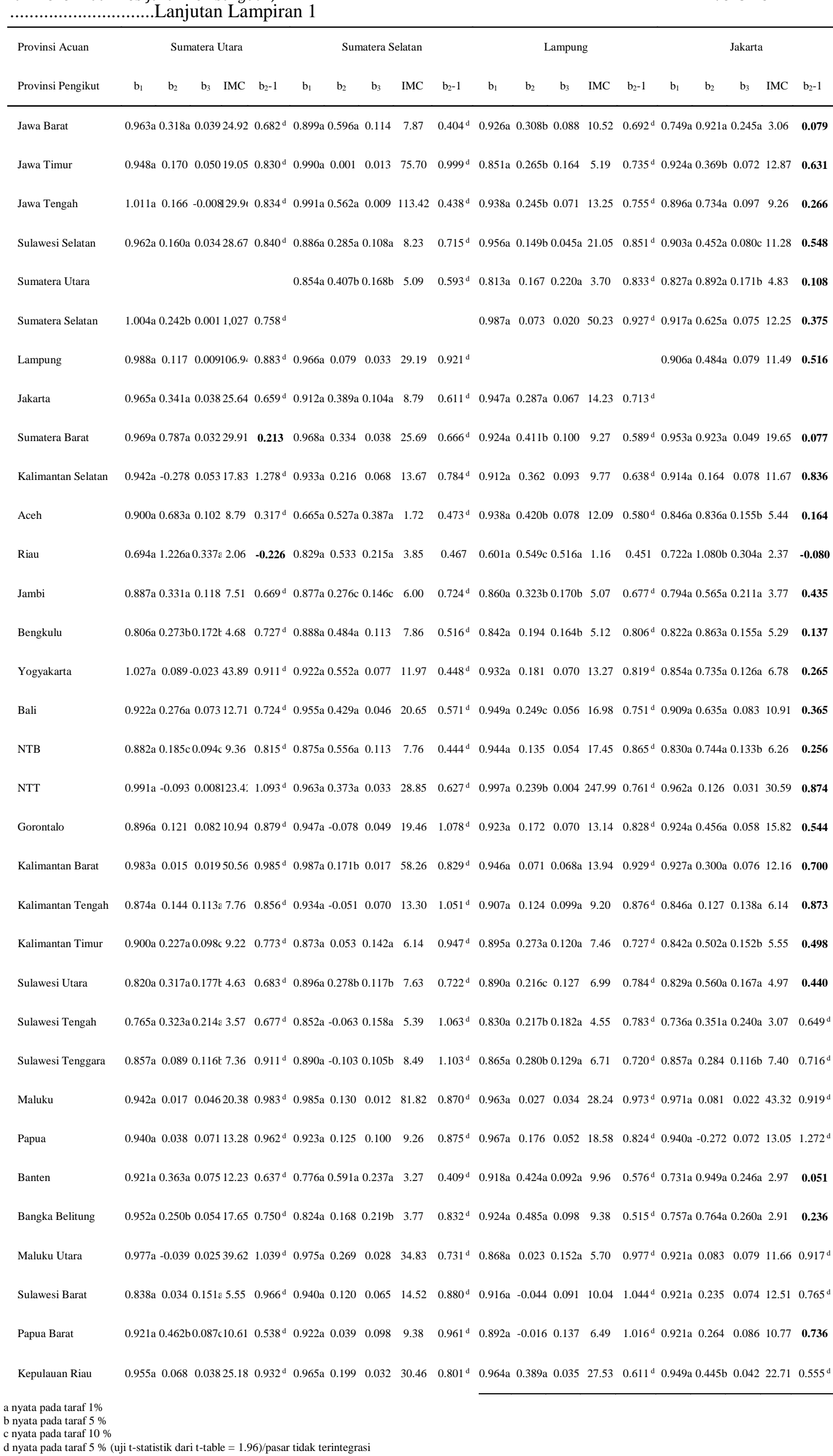


Lampiran 2. Hasil Pendugaan Regresi Model Ravallion Komoditi Gula di Indonesia

\begin{tabular}{|c|c|c|c|c|c|c|c|c|c|c|c|c|c|c|c|c|c|c|c|c|}
\hline \multirow{2}{*}{$\begin{array}{l}\text { Provinsi Acuan } \\
\text { Provinsi Pengikut }\end{array}$} & \multicolumn{5}{|c|}{ Jawa Barat } & \multicolumn{5}{|c|}{ Jawa Timur } & \multicolumn{5}{|c|}{ Jawa Tengah } & \multicolumn{5}{|c|}{ Sulawesi Selatan } \\
\hline & $b_{1}$ & $b_{2}$ & $b_{3}$ & IMC & $b_{2}-1$ & $b_{1}$ & $b_{2}$ & $b_{3}$ & IMC & $b_{2}-1$ & $b_{1}$ & $b_{2}$ & $b_{3}$ & IMC & $b_{2}-1$ & $b_{1}$ & $b_{2}$ & $b_{3}$ & IMC & $b_{2}-1$ \\
\hline Jawa Barat & & & & & & $0.679 a$ & $0.534 \mathrm{a}$ & $0.353 a$ & 1.923 & $-0.466^{\mathrm{d}}$ & $0.718 \mathrm{a}$ & $0.541 \mathrm{a}$ & $0.303 \mathrm{a}$ & 2.369 & $-0.459^{d}$ & $0.722 \mathrm{a}$ & $0.513 \mathrm{a}$ & $0.296 \mathrm{a}$ & 2.441 & $-0.487^{\mathrm{d}}$ \\
\hline Jawa Timur & $0.770 \mathrm{a}$ & $0.802 \mathrm{a}$ & $0.210 \mathrm{~b}$ & 3.674 & -0.198 & & & & & & $0.415 a$ & $0.987 \mathrm{a}$ & $0.572 \mathrm{a}$ & 0.726 & -0.013 & $0.837 \mathrm{a}$ & $0.505 \mathrm{a}$ & $0.159 b$ & 5.280 & $-0.495^{d}$ \\
\hline Jawa Tengah & $0.893 \mathrm{a}$ & 0.606 & 0.100 & 8.897 & $-0.394^{d}$ & $0.540 \mathrm{a}$ & $0.824 \mathrm{a}$ & $0.471 \mathrm{a}$ & 1.147 & $-0.176^{d}$ & & & & & & $0.903 \mathrm{a}$ & $0.426 \mathrm{a}$ & 0.097 & 9.331 & $-0.574^{d}$ \\
\hline Sulawesi Selatan & $0.627 \mathrm{a}$ & $0.903 \mathrm{a}$ & $0.352 \mathrm{a}$ & 1.781 & -0.097 & $0.747 a$ & $0.697 \mathrm{a}$ & $0.262 \mathrm{a}$ & 2.850 & $-0.303^{d}$ & $0.773 \mathrm{a}$ & $0.755 \mathrm{a}$ & $0.230 \mathrm{a}$ & 3.366 & -0.245 & & & & & \\
\hline Sumatera Utara & $0.795 \mathrm{a}$ & $0.668 \mathrm{a}$ & $0.200 \mathrm{c}$ & 3.970 & $-0.332^{d}$ & $0.675 \mathrm{a}$ & $0.759 a$ & $0.349 \mathrm{a}$ & 1.935 & $-0.241^{\mathrm{d}}$ & $0.769 \mathrm{a}$ & $0.896 \mathrm{a}$ & $0.242 \mathrm{a}$ & 3.186 & -0.104 & $0.863 \mathrm{a}$ & $0.464 a$ & 0.143 & 6.047 & $-0.536^{\mathrm{d}}$ \\
\hline Sumatera Selatan & $0.692 \mathrm{a}$ & $0.672 \mathrm{a}$ & 0.297 & 2.329 & $-0.328^{d}$ & $0.623 a$ & $0.674 \mathrm{a}$ & $0.398 \mathrm{a}$ & 1.566 & $-0.326^{d}$ & $0.701 \mathrm{a}$ & 0.751a & $0.309 \mathrm{a}$ & 2.268 & $-0.249^{d}$ & $0.701 \mathrm{a}$ & $0.417 \mathrm{a}$ & 0.307 & 2.281 & $-0.583^{d}$ \\
\hline Lampung & $0.830 \mathrm{a}$ & $0.693 \mathrm{a}$ & $0.155 \mathrm{a}$ & 5.338 & $-0.307^{d}$ & 0.401a & $0.604 a$ & $0.597 \mathrm{a}$ & 0.672 & $-0.396^{d}$ & $0.478 \mathrm{a}$ & $0.676 \mathrm{a}$ & $0.509 \mathrm{a}$ & 0.939 & $-0.324^{d}$ & $0.836 \mathrm{a}$ & $0.440 \mathrm{a}$ & $0.160 \mathrm{~b}$ & 5.220 & $-0.560^{\mathrm{d}}$ \\
\hline Jakarta & $0.689 \mathrm{a}$ & $0.534 a$ & $0.322 \mathrm{a}$ & 2.136 & $-0.466^{\mathrm{d}}$ & $0.674 a$ & $0.406 \mathrm{a}$ & $0.370 \mathrm{a}$ & 1.822 & $-0.594^{\mathrm{d}}$ & $0.704 a$ & $0.498 \mathrm{a}$ & $0.328 \mathrm{a}$ & 2.145 & $-0.502^{\mathrm{d}}$ & $0.788 \mathrm{a}$ & $0.345 \mathrm{a}$ & $0.234 a$ & 3.364 & $-0.655^{d}$ \\
\hline Aceh & $0.788 \mathrm{a}$ & $0.584 \mathrm{a}$ & $0.228 \mathrm{a}$ & 3.455 & $0.416^{\mathrm{d}}$ & $0.737 \mathrm{a}$ & $0.780 \mathrm{a}$ & $0.309 \mathrm{a}$ & 2.389 & $-0.220^{\mathrm{d}}$ & $0.752 \mathrm{a}$ & $0.837 \mathrm{a}$ & $0.285 \mathrm{a}$ & 2.641 & -0.163 & $0.770 \mathrm{a}$ & $0.421 \mathrm{a}$ & $0.263 \mathrm{a}$ & 2.927 & $-0.579^{\mathrm{d}}$ \\
\hline Sumatera Barat & $0.871 \mathrm{a}$ & 0.752 & 0.126 & 6.911 & $0.248^{d}$ & $0.526 \mathrm{a}$ & $0.724 a$ & $0.510 \mathrm{a}$ & 1.030 & $-0.276^{\mathrm{d}}$ & $0.627 \mathrm{a}$ & $0.808 \mathrm{a}$ & $0.392 \mathrm{a}$ & 1.600 & $-0.192^{d}$ & $0.889 \mathrm{a}$ & $0.501 \mathrm{a}$ & $0.116 \mathrm{c}$ & 7.636 & $-0.499^{\mathrm{d}}$ \\
\hline Riau & $0.696 \mathrm{a}$ & $0.750 \mathrm{a}$ & $0.317 \mathrm{a}$ & 2.195 & -0.250 & $0.718 \mathrm{a}$ & $0.638 \mathrm{a}$ & $0.322 \mathrm{a}$ & 2.227 & $-0.362^{\mathrm{d}}$ & $0.738 \mathrm{a}$ & $0.673 a$ & $0.293 \mathrm{a}$ & 2.521 & $-0.327^{d}$ & $0.835 \mathrm{a}$ & $0.497 \mathrm{a}$ & $0.184 b$ & 4.548 & $-0.503^{\mathrm{d}}$ \\
\hline Jambi & $0.794 a$ & $0.504 a$ & $0.202 \mathrm{a}$ & 3.935 & $-0.496^{\mathrm{d}}$ & $0.507 \mathrm{a}$ & $0.538 \mathrm{a}$ & $0.528 \mathrm{a}$ & 0.960 & $-0.462^{\mathrm{d}}$ & $0.593 \mathrm{a}$ & $0.668 \mathrm{a}$ & $0.425 \mathrm{a}$ & 1.395 & $-0.332^{d}$ & $0.819 \mathrm{a}$ & $0.340 \mathrm{a}$ & $0.189 \mathrm{a}$ & 4.338 & $-0.660^{\mathrm{d}}$ \\
\hline Bengkulu & $0.792 \mathrm{a}$ & $0.611 \mathrm{a}$ & $0.194 a$ & 4.086 & $-0.389^{d}$ & $0.429 a$ & $0.591 \mathrm{a}$ & $0.582 \mathrm{a}$ & 0.737 & $-0.409^{\mathrm{d}}$ & $0.473 \mathrm{a}$ & $0.706 \mathrm{a}$ & $0.525 \mathrm{a}$ & 0.901 & $-0.294^{d}$ & $0.798 \mathrm{a}$ & $0.380 \mathrm{a}$ & $0.201 \mathrm{a}$ & 3.969 & $-0.620^{\mathrm{d}}$ \\
\hline Yogyakarta & $0.812 \mathrm{a}$ & 0.766 & $0.170 \mathrm{a}$ & 4.779 & -0.234 & $0.693 a$ & $0.830 \mathrm{a}$ & $0.305 \mathrm{a}$ & 2.271 & $-0.170^{\mathrm{d}}$ & $0.738 \mathrm{a}$ & $0.885 a$ & $0.255 \mathrm{a}$ & 2.901 & -0.115 & $0.900 \mathrm{a}$ & $0.604 a$ & $0.096 \mathrm{a}$ & 9.352 & $-0.396^{\mathrm{d}}$ \\
\hline Bali & $0.624 a$ & $0.667 \mathrm{a}$ & 0.363 & 1.718 & $-0.333^{d}$ & $0.488 \mathrm{a}$ & $0.507 \mathrm{a}$ & $0.541 \mathrm{a}$ & 0.902 & $-0.493^{\mathrm{d}}$ & $0.488 \mathrm{a}$ & $0.511 a$ & $0.529 \mathrm{a}$ & 0.922 & $-0.489^{d}$ & $0.716 \mathrm{a}$ & $0.363 \mathrm{a}$ & 0.292 & 2.451 & $-0.637^{\mathrm{d}}$ \\
\hline NTB & $0.898 \mathrm{a}$ & $0.660 \mathrm{a}$ & 0.094 & 9.576 & $-0.340^{\mathrm{d}}$ & $0.622 \mathrm{a}$ & $0.684 a$ & $0.380 \mathrm{a}$ & 1.636 & $-0.316^{\mathrm{d}}$ & $0.674 a$ & $0.767 \mathrm{a}$ & $0.320 \mathrm{a}$ & 2.106 & $-0.233^{d}$ & $0.902 \mathrm{a}$ & $0.449 \mathrm{a}$ & $0.097 \mathrm{a}$ & 9.290 & $-0.551^{\mathrm{d}}$ \\
\hline NTT & $0.816 \mathrm{a}$ & $0.308 \mathrm{a}$ & $0.189 \mathrm{a}$ & 4.309 & $-0.692^{d}$ & $0.766 \mathrm{a}$ & $0.295 \mathrm{a}$ & $0.262 \mathrm{a}$ & 2.919 & $-0.705^{\mathrm{d}}$ & $0.788 \mathrm{a}$ & $0.307 \mathrm{a}$ & $0.232 \mathrm{a}$ & 3.393 & $-0.693^{d}$ & $0.796 \mathrm{a}$ & 0.249 & 0.221 & 3.599 & $-0.751^{\mathrm{d}}$ \\
\hline Gorontalo & $0.783 a$ & $0.567 \mathrm{a}$ & 0.213 & 3.672 & $-0.433^{\mathrm{d}}$ & $0.527 \mathrm{a}$ & $0.479 \mathrm{a}$ & $0.507 \mathrm{a}$ & 1.039 & $-0.521^{\mathrm{d}}$ & $0.597 \mathrm{a}$ & $0.647 \mathrm{a}$ & $0.422 \mathrm{a}$ & 1.416 & $-0.353^{d}$ & $0.800 \mathrm{a}$ & $0.309 \mathrm{a}$ & 0.209 & 3.821 & $-0.691^{\mathrm{d}}$ \\
\hline Kalimantan Barat & $0.832 \mathrm{a}$ & 0.311 & $0.153 \mathrm{c}$ & 5.443 & $-0.689^{\mathrm{d}}$ & $0.723 \mathrm{a}$ & $0.626 \mathrm{a}$ & $0.274 a$ & 2.634 & $-0.374^{d}$ & $0.716 \mathrm{a}$ & $0.628 \mathrm{a}$ & $0.275 \mathrm{a}$ & 2.609 & -0.372 & $0.828 \mathrm{a}$ & $0.420 \mathrm{a}$ & $0.166 \mathrm{~b}$ & 4.982 & $-0.580^{\mathrm{d}}$ \\
\hline Kalimantan Tengah & $0.611 \mathrm{a}$ & $0.943 \mathrm{a}$ & $0.363 \mathrm{a}$ & 1.682 & -0.057 & $0.646 \mathrm{a}$ & $0.731 \mathrm{a}$ & $0.362 \mathrm{a}$ & 1.785 & $-0.269^{d}$ & $0.699 a$ & $0.717 \mathrm{a}$ & $0.302 \mathrm{a}$ & 2.318 & $-0.283^{d}$ & $0.598 \mathrm{a}$ & 0.758 & $0.399 \mathrm{a}$ & 1.498 & $-0.242^{\mathrm{d}}$ \\
\hline Kalimantan Selatan & $0.684 \mathrm{a}$ & $0.951 \mathrm{a}$ & 0.286 & 2.391 & -0.049 & $0.728 \mathrm{a}$ & $0.830 \mathrm{a}$ & $0.270 \mathrm{a}$ & 2.696 & -0.170 & $0.739 \mathrm{a}$ & $0.826 \mathrm{a}$ & $0.254 \mathrm{a}$ & 2.904 & -0.174 & $0.726 \mathrm{a}$ & 0.803 & 0.264 & 2.751 & $-0.197^{d}$ \\
\hline Kalimantan Timur & $0.768 \mathrm{a}$ & $0.972 \mathrm{a}$ & $0.225 \mathrm{a}$ & 3.412 & -0.028 & $0.617 \mathrm{a}$ & $0.790 \mathrm{a}$ & $0.408 \mathrm{a}$ & 1.510 & $-0.210^{\mathrm{d}}$ & $0.704 \mathrm{a}$ & $0.825 \mathrm{a}$ & $0.308 \mathrm{a}$ & 2.286 & -0.175 & $0.759 \mathrm{a}$ & $0.660 \mathrm{a}$ & $0.249 \mathrm{a}$ & 3.048 & $-0.340^{\mathrm{d}}$ \\
\hline Sulawesi Utara & $0.676 \mathrm{a}$ & $0.867 \mathrm{a}$ & $0.320 \mathrm{a}$ & 2.113 & -0.133 & $0.727 \mathrm{a}$ & $0.495 \mathrm{a}$ & $0.296 \mathrm{a}$ & 2.455 & $-0.505^{\mathrm{d}}$ & $0.755 \mathrm{a}$ & $0.493 \mathrm{a}$ & $0.261 \mathrm{a}$ & 2.892 & $-0.507^{\mathrm{d}}$ & $0.708 \mathrm{a}$ & $0.696 \mathrm{a}$ & $0.306 \mathrm{a}$ & 2.311 & -0.304 \\
\hline Sulawesi Tengah & $0.840 \mathrm{a}$ & $0.599 \mathrm{a}$ & $0.161 \mathrm{a}$ & 5.226 & $-0.401^{\mathrm{d}}$ & $0.673 \mathrm{a}$ & $0.489 \mathrm{a}$ & $0.357 \mathrm{a}$ & 1.885 & $-0.511^{\mathrm{d}}$ & $0.717 \mathrm{a}$ & $0.541 \mathrm{a}$ & $0.302 \mathrm{a}$ & 2.373 & $-0.459^{d}$ & $0.873 \mathrm{a}$ & $0.456 \mathrm{a}$ & $0.136 \mathrm{a}$ & 6.420 & -0.544 \\
\hline Sulawesi Tenggara & $0.656 \mathrm{a}$ & $0.558 \mathrm{a}$ & $0.332 \mathrm{a}$ & 1.978 & $-0.442^{\mathrm{d}}$ & $0.633 \mathrm{a}$ & $0.296 \mathrm{~b}$ & $0.388 \mathrm{a}$ & 1.632 & $-0.704^{\mathrm{d}}$ & $0.648 \mathrm{a}$ & $0.327 \mathrm{~b}$ & $0.364 \mathrm{a}$ & 1.779 & $-0.673^{d}$ & $0.697 \mathrm{a}$ & 0.565 & $0.310 \mathrm{a}$ & 2.247 & $-0.435^{\mathrm{d}}$ \\
\hline Maluku & $0.804 \mathrm{a}$ & 0.644 & 0.207 & 3.890 & $-0.356^{\mathrm{d}}$ & $0.643 \mathrm{a}$ & $0.491 \mathrm{a}$ & $0.410 \mathrm{a}$ & 1.567 & $-0.509^{\mathrm{d}}$ & $0.633 \mathrm{a}$ & $0.490 \mathrm{a}$ & $0.412 \mathrm{a}$ & 1.536 & $-0.510^{d}$ & $0.867 \mathrm{a}$ & 0.405 & 0.149 & 5.811 & -0.595 \\
\hline Papua & $0.826 \mathrm{a}$ & $0.345 \mathrm{a}$ & 0.204 & 4.053 & $-0.655^{\mathrm{d}}$ & $0.859 \mathrm{a}$ & $0.306 \mathrm{a}$ & $0.181 \mathrm{a}$ & 4.760 & $-0.694^{d}$ & $0.869 \mathrm{a}$ & $0.409 \mathrm{a}$ & $0.164 \mathrm{a}$ & 5.309 & $-0.591^{\mathrm{d}}$ & $0.844 \mathrm{a}$ & 0.288 & 0.193 & 4.367 & $-0.712^{\mathrm{d}}$ \\
\hline Banten & $0.339 \mathrm{a}$ & $0.718 \mathrm{a}$ & $0.656 \mathrm{a}$ & 0.518 & $-0.282^{\mathrm{d}}$ & $0.630 \mathrm{a}$ & $0.475 \mathrm{a}$ & $0.402 \mathrm{a}$ & 1.567 & $-0.525^{d}$ & $0.659 \mathrm{a}$ & $0.468 \mathrm{a}$ & $0.364 a$ & 1.811 & $-0.532^{d}$ & $0.534 \mathrm{a}$ & $0.508 \mathrm{a}$ & $0.491 \mathrm{a}$ & 1.087 & -0.492 \\
\hline Bangka Belitung & $0.773 a$ & $0.575 \mathrm{a}$ & $0.222 \mathrm{a}$ & 3.479 & $-0.425^{\mathrm{d}}$ & $0.439 \mathrm{a}$ & $0.664 \mathrm{a}$ & $0.597 \mathrm{a}$ & 0.736 & $-0.336^{\mathrm{d}}$ & $0.464 a$ & $0.803 \mathrm{a}$ & $0.558 \mathrm{a}$ & 0.832 & $-0.197^{d}$ & $0.850 \mathrm{a}$ & $0.448 \mathrm{a}$ & $0.156 \mathrm{~b}$ & 5.431 & $-0.552^{\mathrm{d}}$ \\
\hline Maluku Utara & $0.717 \mathrm{a}$ & $0.407 \mathrm{a}$ & $0.308 \mathrm{a}$ & 2.331 & $-0.593^{d}$ & $0.727 \mathrm{a}$ & $0.395 a$ & $0.324 a$ & 2.246 & $-0.605^{\mathrm{d}}$ & $0.751 \mathrm{a}$ & $0.478 a$ & $0.289 \mathrm{a}$ & 2.594 & $-0.522^{d}$ & $0.733 \mathrm{a}$ & 0.279 & 0.308 & 2.376 & $-0.721^{\mathrm{d}}$ \\
\hline Sulawesi Barat & $0.624 \mathrm{a}$ & $0.506 \mathrm{~b}$ & 0.380 & 1.640 & $-0.494^{d}$ & $0.560 \mathrm{a}$ & 0.319 & $0.487 \mathrm{a}$ & 1.152 & $-0.681^{\mathrm{d}}$ & $0.499 \mathrm{a}$ & 0.155 & $0.543 \mathrm{a}$ & 0.918 & $-0.845^{\mathrm{d}}$ & $0.707 \mathrm{a}$ & $0.516 \mathrm{a}$ & 0.313 & 2.259 & $-0.484^{d}$ \\
\hline Papua Barat & $0.901 \mathrm{a}$ & $0.318 \mathrm{a}$ & $0.110 \mathrm{c}$ & 8.172 & $-0.682^{\mathrm{d}}$ & $0.833 \mathrm{a}$ & 0.175 & $0.202 \mathrm{a}$ & 4.115 & $-0.825^{\mathrm{d}}$ & $0.833 \mathrm{a}$ & 0.214 & $0.198 \mathrm{a}$ & 4.202 & $-0.786^{d}$ & $0.913 \mathrm{a}$ & $0.239 \mathrm{~b}$ & $0.104 \mathrm{~b}$ & 8.768 & $-0.761^{d}$ \\
\hline Kepulauan Riau & $0.981 \mathrm{a}$ & $0.267 \mathrm{c}$ & 0.011 & 91.365 & $-0.733^{d}$ & $0.972 \mathrm{a}$ & $0.260 \mathrm{~b}$ & 0.021 & 46.757 & $-0.740^{d}$ & $0.975 \mathrm{a}$ & $0.357 \mathrm{a}$ & 0.017 & 56.161 & $-0.643^{d}$ & $0.969 \mathrm{a}$ & $0.171 \mathrm{c}$ & 0.023 & 41.646 & $-0.829^{d}$ \\
\hline
\end{tabular}


Lanjutan Lampiran 2

\begin{tabular}{|c|c|c|c|c|c|c|c|c|c|c|c|c|c|c|c|c|c|c|c|c|}
\hline \multirow{2}{*}{$\begin{array}{l}\text { Provinsi Acuan } \\
\text { Provinsi Pengikut }\end{array}$} & \multicolumn{5}{|c|}{ Sumatera Utara } & \multicolumn{5}{|c|}{ Sumatera Selatan } & \multicolumn{5}{|c|}{ Lampung } & \multicolumn{5}{|c|}{ Jakarta } \\
\hline & $b_{1}$ & $b_{2}$ & $b_{3}$ & IMC & $b_{2}-1$ & $b_{1}$ & $b_{2}$ & $b_{3}$ & IMC & $b_{2}-1$ & $b_{1}$ & $b_{2}$ & $b_{3}$ & IMC & $b_{2}-1$ & $b_{1}$ & $b_{2}$ & $b_{3}$ & IMC & $b_{2}-1$ \\
\hline Jawa Barat & $0.592 \mathrm{a}$ & $0.404 \mathrm{a}$ & $0.417 \mathrm{a}$ & 1.420 & $-0.596^{\mathrm{d}}$ & $0.742 \mathrm{a}$ & $0.576 \mathrm{a}$ & $0.270 \mathrm{a}$ & 2.743 & $-0.424^{d}$ & $0.812 \mathrm{a}$ & 0.630a & $0.209 \mathrm{a}$ & 3.886 & $-0.370^{d}$ & $0.677 \mathrm{a}$ & $0.810 \mathrm{a}$ & $0.314 \mathrm{a}$ & 2.157 & -0.190 \\
\hline Jawa Timur & $0.559 \mathrm{a}$ & $0.703 \mathrm{a}$ & 0.411 & 1.363 & $-0.297^{d}$ & $0.754 a$ & $0.806 \mathrm{a}$ & $0.233 \mathrm{~b}$ & 3.236 & -0.194 & $0.492 \mathrm{a}$ & $0.895 \mathrm{a}$ & $0.511 \mathrm{a}$ & 0.963 & -0.105 & $0.692 \mathrm{a}$ & $0.980 \mathrm{a}$ & $0.273 \mathrm{a}$ & 2.536 & -0.020 \\
\hline Jawa Tengah & $0.761 \mathrm{a}$ & $0.699 \mathrm{a}$ & 0.228 & 3.337 & $-0.301^{d}$ & $0.881 \mathrm{a}$ & $0.656 \mathrm{a}$ & 0.116 & 7.602 & $-0.344^{d}$ & $0.702 \mathrm{a}$ & $0.752 \mathrm{a}$ & $0.306 \mathrm{~b}$ & 2.292 & $-0.248^{d}$ & $0.823 \mathrm{a}$ & $0.877 \mathrm{a}$ & $0.160 \mathrm{c}$ & 5.144 & -0.123 \\
\hline Sulawesi Selatan & $0.666 \mathrm{a}$ & $0.621 \mathrm{a}$ & $0.322 \mathrm{a}$ & 2.071 & $-0.379^{d}$ & $0.704 \mathrm{a}$ & $0.672 \mathrm{a}$ & $0.291 \mathrm{a}$ & 2.416 & $-0.328^{d}$ & $0.813 a$ & $0.740 \mathrm{a}$ & $0.195 \mathrm{~b}$ & 4.170 & -0.260 & $0.707 \mathrm{a}$ & $0.928 \mathrm{a}$ & $0.268 \mathrm{a}$ & 2.635 & -0.072 \\
\hline Sumatera Utara & & & & & & $0.895 \mathrm{a}$ & $0.656 \mathrm{a}$ & 0.105 & 8.524 & $-0.344^{d}$ & $0.868 \mathrm{a}$ & $0.806 \mathrm{a}$ & 0.141 & 6.151 & -0.194 & $0.794 a$ & $1.018 \mathrm{a}$ & $0.194 \mathrm{a}$ & 4.100 & 0.018 \\
\hline Sumatera Selatan & $0.624 \mathrm{a}$ & $0.537 \mathrm{a}$ & 0.369 & 1.688 & $-0.463^{d}$ & & & & & & 0.760a & $0.866 \mathrm{a}$ & $0.255 \mathrm{a}$ & 2.982 & -0.134 & $0.627 \mathrm{a}$ & $1.022 \mathrm{a}$ & $0.348 b$ & 1.799 & 0.022 \\
\hline Lampung & $0.707 \mathrm{a}$ & $0.631 \mathrm{a}$ & 0.273 & 2.587 & $-0.369^{\mathrm{d}}$ & $0.777 \mathrm{a}$ & $0.777 \mathrm{a}$ & $0.211 \mathrm{a}$ & 3.677 & $-0.223^{d}$ & & & & & & $0.795 \mathrm{a}$ & $1.043 \mathrm{a}$ & $0.180 \mathrm{a}$ & 4.403 & 0.043 \\
\hline Jakarta & $0.710 \mathrm{a}$ & $0.439 \mathrm{a}$ & $0.305 \mathrm{a}$ & 2.327 & $-0.561^{\mathrm{d}}$ & $0.688 \mathrm{a}$ & $0.554 \mathrm{a}$ & $0.335 \mathrm{a}$ & 2.053 & $-0.446^{d}$ & $0.817 \mathrm{a}$ & $0.655 \mathrm{a}$ & $0.209 \mathrm{a}$ & 3.900 & $-0.345^{\mathrm{d}}$ & & & & & \\
\hline Aceh & $0.786 \mathrm{a}$ & 0.750a & $0.235 \mathrm{a}$ & 3.344 & $-0.250^{d}$ & $0.692 \mathrm{a}$ & 0.732a & $0.344 a$ & 2.010 & $-0.268^{d}$ & $0.712 \mathrm{a}$ & $0.708 \mathrm{a}$ & 0.340a & 2.095 & $-0.292^{d}$ & $0.726 \mathrm{a}$ & $0.806 \mathrm{a}$ & $0.286 \mathrm{a}$ & 2.542 & -0.194 \\
\hline Sumatera Barat & $0.664 \mathrm{a}$ & $0.688 \mathrm{a}$ & 0.337 & 1.968 & $-0.312^{d}$ & $0.929 \mathrm{a}$ & $0.721 \mathrm{a}$ & 0.071 & 13.079 & $-0.279^{d}$ & $0.731 \mathrm{a}$ & $0.875 \mathrm{a}$ & $0.290 \mathrm{~b}$ & 2.519 & -0.125 & $0.848 \mathrm{a}$ & $1.004 a$ & $0.143 b$ & 5.914 & 0.004 \\
\hline Riau & $0.683 a$ & $0.564 \mathrm{a}$ & $0.337 \mathrm{a}$ & 2.026 & $-0.436^{d}$ & $0.813 a$ & $0.681 \mathrm{a}$ & $0.203 \mathrm{~b}$ & 4.004 & $-0.319^{d}$ & $0.715 \mathrm{a}$ & $0.707 \mathrm{a}$ & $0.328 \mathrm{a}$ & 2.181 & $-0.293^{d}$ & $0.731 \mathrm{a}$ & $0.908 \mathrm{a}$ & $0.272 \mathrm{a}$ & 2.684 & -0.092 \\
\hline Jambi & $0.662 \mathrm{a}$ & $0.506 \mathrm{a}$ & $0.336 a$ & 1.969 & $-0.494^{d}$ & $0.774 \mathrm{a}$ & $0.688 \mathrm{a}$ & $0.230 \mathrm{~b}$ & 3.368 & $-0.312^{\mathrm{d}}$ & $0.401 \mathrm{a}$ & $0.807 \mathrm{a}$ & $0.644 \mathrm{a}$ & 0.623 & $-0.193^{\mathrm{d}}$ & $0.801 \mathrm{a}$ & 0.94la & $0.187 \mathrm{~b}$ & 4.279 & -0.059 \\
\hline Bengkulu & $0.538 \mathrm{a}$ & $0.527 \mathrm{a}$ & $0.438 \mathrm{a}$ & 1.229 & $-0.473^{\mathrm{d}}$ & $0.737 \mathrm{a}$ & $0.719 \mathrm{a}$ & $0.255 b$ & 2.891 & $-0.281^{\mathrm{d}}$ & $0.541 \mathrm{a}$ & $0.877 \mathrm{a}$ & 0.470a & 1.151 & $-0.123^{\mathrm{d}}$ & $0.775 \mathrm{a}$ & 0.999 & $0.202 b$ & 3.846 & -0.001 \\
\hline Yogyakarta & $0.654 a$ & $0.769 \mathrm{a}$ & $0.321 \mathrm{a}$ & 2.033 & $-0.231^{\mathrm{d}}$ & $0.893 a$ & $0.606 \mathrm{a}$ & 0.100 & 8.914 & $-0.394^{d}$ & $0.852 \mathrm{a}$ & $0.704 a$ & 0.148 & 5.754 & -0.296 & $0.823 \mathrm{a}$ & $0.856 \mathrm{a}$ & $0.155 \mathrm{c}$ & 5.322 & -0.144 \\
\hline Bali & $0.601 \mathrm{a}$ & $0.496 \mathrm{a}$ & 0.392 & 1.536 & $-0.504^{d}$ & $0.632 \mathrm{a}$ & $0.567 \mathrm{a}$ & 0.370a & 1.707 & $-0.433^{\mathrm{d}}$ & $0.595 \mathrm{a}$ & $0.603 a$ & $0.431 \mathrm{a}$ & 1.380 & $-0.397^{d}$ & $0.417 \mathrm{a}$ & $1.020 \mathrm{a}$ & $0.546 \mathrm{a}$ & 0.764 & 0.020 \\
\hline NTB & $0.757 \mathrm{a}$ & $0.555 \mathrm{a}$ & $0.228 \mathrm{a}$ & 3.321 & $-0.445^{d}$ & $0.888 \mathrm{a}$ & $0.622 \mathrm{a}$ & 0.107 & 8.270 & $-0.378^{d}$ & $0.605 \mathrm{a}$ & $0.811 \mathrm{a}$ & $0.398 \mathrm{a}$ & 1.520 & $-0.189^{d}$ & $0.870 \mathrm{a}$ & $0.915 \mathrm{a}$ & $0.115 \mathrm{c}$ & 7.598 & -0.085 \\
\hline NTT & $0.724 a$ & $0.195 \mathrm{c}$ & $0.286 \mathrm{a}$ & 2.532 & $-0.805^{\mathrm{d}}$ & $0.751 \mathrm{a}$ & $0.375 \mathrm{a}$ & $0.265 \mathrm{a}$ & 2.835 & $-0.625^{\mathrm{d}}$ & $0.702 \mathrm{a}$ & $0.449 \mathrm{a}$ & $0.334 \mathrm{a}$ & 2.099 & $-0.551^{d}$ & $0.836 \mathrm{a}$ & $0.631 \mathrm{a}$ & $0.163 \mathrm{~b}$ & 5.132 & $-0.369^{d}$ \\
\hline Gorontalo & $0.687 \mathrm{a}$ & $0.471 \mathrm{a}$ & 0.312 & 2.200 & $-0.529^{d}$ & $0.719 \mathrm{a}$ & $0.580 \mathrm{a}$ & $0.286 \mathrm{a}$ & 2.511 & $-0.420^{d}$ & $0.412 \mathrm{a}$ & $0.681 \mathrm{a}$ & $0.633 \mathrm{a}$ & 0.650 & $-0.319^{d}$ & $0.729 \mathrm{a}$ & $0.819 \mathrm{a}$ & $0.257 \mathrm{~b}$ & 2.837 & -0.181 \\
\hline Kalimantan Barat & $0.700 \mathrm{a}$ & $0.423 \mathrm{a}$ & $0.277 \mathrm{a}$ & 2.530 & $-0.577^{d}$ & $0.783 a$ & $0.650 \mathrm{a}$ & $0.204 \mathrm{~b}$ & 3.843 & $-0.350^{\mathrm{d}}$ & $0.701 \mathrm{a}$ & $0.708 \mathrm{a}$ & $0.297 \mathrm{a}$ & 2.361 & -0.292 & $0.762 \mathrm{a}$ & $0.798 \mathrm{a}$ & $0.208 \mathrm{~b}$ & 3.654 & -0.202 \\
\hline Kalimantan Tengah & $0.548 \mathrm{a}$ & 0.608 & $0.430 \mathrm{a}$ & 1.275 & $-0.392^{\mathrm{d}}$ & $0.572 \mathrm{a}$ & $0.791 \mathrm{a}$ & $0.416 \mathrm{a}$ & 1.375 & -0.209 & $0.755 \mathrm{a}$ & $0.849 \mathrm{a}$ & $0.251 \mathrm{~b}$ & 3.007 & -0.151 & $0.673 \mathrm{a}$ & $1.026 \mathrm{a}$ & $0.296 \mathrm{a}$ & 2.271 & 0.026 \\
\hline Kalimantan Selatan & $0.537 \mathrm{a}$ & 0.671 & 0.429 & 1.252 & $-0.329^{d}$ & $0.663 \mathrm{a}$ & $0.698 \mathrm{a}$ & $0.318 \mathrm{a}$ & 2.083 & $-0.302^{\mathrm{d}}$ & $0.747 \mathrm{a}$ & $0.768 \mathrm{a}$ & $0.253 \mathrm{~b}$ & 2.947 & -0.232 & $0.712 \mathrm{a}$ & $0.873 a$ & $0.254 a$ & 2.803 & -0.127 \\
\hline Kalimantan Timur & $0.565 \mathrm{a}$ & $0.693 \mathrm{a}$ & $0.431 \mathrm{a}$ & 1.312 & $-0.307^{d}$ & $0.762 \mathrm{a}$ & $0.700 \mathrm{a}$ & $0.241 \mathrm{~b}$ & 3.160 & $-0.300^{d}$ & $0.703 a$ & $0.813 a$ & $0.318 a$ & 2.210 & -0.187 & $0.707 a$ & $0.976 \mathrm{a}$ & $0.276 \mathrm{a}$ & 2.565 & -0.024 \\
\hline Sulawesi Utara & $0.648 \mathrm{a}$ & $0.374 a$ & $0.354 a$ & 1.832 & $-0.626^{d}$ & $0.636 \mathrm{a}$ & $0.465 \mathrm{a}$ & $0.375 \mathrm{a}$ & 1.696 & $-0.535^{d}$ & $0.775 \mathrm{a}$ & $0.633 \mathrm{a}$ & $0.245 \mathrm{a}$ & 3.162 & $-0.367^{\mathrm{d}}$ & $0.716 \mathrm{a}$ & $0.923 \mathrm{a}$ & $0.272 \mathrm{a}$ & 2.634 & -0.077 \\
\hline Sulawesi Tengah & $0.739 \mathrm{a}$ & $0.450 \mathrm{a}$ & $0.266 \mathrm{a}$ & 2.782 & $-0.550^{d}$ & $0.807 \mathrm{a}$ & $0.502 \mathrm{a}$ & $0.201 \mathrm{a}$ & 4.021 & $-0.498^{d}$ & $0.741 \mathrm{a}$ & $0.623 a$ & $0.284 a$ & 2.609 & $-0.377^{d}$ & $0.822 \mathrm{a}$ & $0.791 \mathrm{a}$ & $0.172 \mathrm{c}$ & 4.770 & $-0.209^{\mathrm{d}}$ \\
\hline Sulawesi Tenggara & $0.560 \mathrm{a}$ & 0.200 & 0.431a & 1.301 & $-0.800^{d}$ & $0.602 \mathrm{a}$ & $0.454 \mathrm{a}$ & $0.400 \mathrm{a}$ & 1.506 & $-0.546^{\mathrm{d}}$ & $0.636 \mathrm{a}$ & $0.520 \mathrm{a}$ & $0.386 \mathrm{a}$ & 1.651 & $-0.480^{d}$ & $0.644 \mathrm{a}$ & $0.765 \mathrm{a}$ & $0.333 \mathrm{a}$ & 1.937 & -0.235 \\
\hline Maluku & $0.694 a$ & 0.433 & 0.327 & 2.120 & $-0.567^{\mathrm{d}}$ & $0.709 \mathrm{a}$ & $0.490 \mathrm{a}$ & $0.319 \mathrm{a}$ & 2.226 & $-0.510^{d}$ & $0.652 \mathrm{a}$ & $0.603 a$ & $0.402 \mathrm{a}$ & 1.622 & $-0.397^{d}$ & $0.715 \mathrm{a}$ & $0.845 \mathrm{a}$ & $0.290 \mathrm{a}$ & 2.464 & -0.155 \\
\hline Papua & $0.816 \mathrm{a}$ & 0.346 & 0.218 & 3.739 & $-0.654^{\mathrm{d}}$ & $0.845 \mathrm{a}$ & $0.388 \mathrm{a}$ & $0.189 a$ & 4.465 & $-0.612^{\mathrm{d}}$ & $0.894 \mathrm{a}$ & $0.508 \mathrm{a}$ & $0.137 \mathrm{~b}$ & 6.512 & $-0.492^{\mathrm{d}}$ & $0.856 \mathrm{a}$ & $0.715 \mathrm{a}$ & $0.162 \mathrm{~b}$ & 5.272 & $-0.285^{\mathrm{d}}$ \\
\hline Banten & $0.595 \mathrm{a}$ & $0.400 \mathrm{a}$ & $0.410 \mathrm{a}$ & 1.452 & $-0.600^{d}$ & $0.550 \mathrm{a}$ & $0.627 \mathrm{a}$ & $0.465 \mathrm{a}$ & 1.181 & $-0.373^{d}$ & $0.765 \mathrm{a}$ & $0.603 a$ & $0.258 \mathrm{a}$ & 2.961 & $-0.397^{d}$ & $0.602 \mathrm{a}$ & $0.979 \mathrm{a}$ & $0.383 a$ & 1.571 & -0.021 \\
\hline Bangka Belitung & $0.712 \mathrm{a}$ & $0.635 \mathrm{a}$ & $0.286 \mathrm{a}$ & 2.487 & $-0.365^{d}$ & $0.740 \mathrm{a}$ & $0.674 \mathrm{a}$ & $0.263 \mathrm{~b}$ & 2.815 & $-0.326^{d}$ & $0.453 \mathrm{a}$ & $0.829 \mathrm{a}$ & $0.585 \mathrm{a}$ & 0.774 & -0.171 & 0.698a & $0.852 \mathrm{a}$ & $0.285 \mathrm{a}$ & 2.445 & -0.148 \\
\hline Maluku Utara & $0.658 \mathrm{a}$ & $0.289 \mathrm{~b}$ & $0.376 \mathrm{a}$ & 1.749 & $-0.711^{\mathrm{d}}$ & $0.728 \mathrm{a}$ & $0.491 \mathrm{a}$ & $0.307 \mathrm{a}$ & 2.376 & $-0.509^{d}$ & $0.703 a$ & $0.519 \mathrm{a}$ & 0.354 & 1.984 & $-0.481^{\mathrm{d}}$ & $0.710 \mathrm{a}$ & $0.775 \mathrm{a}$ & $0.304 a$ & 2.336 & -0.225 \\
\hline Sulawesi Barat & $0.579 \mathrm{a}$ & $0.215 \mathrm{a}$ & $0.433 \mathrm{a}$ & 1.337 & $-0.785^{d}$ & $0.598 \mathrm{a}$ & $0.468 \mathrm{~b}$ & $0.424 \mathrm{a}$ & 1.410 & $-0.532^{\mathrm{d}}$ & $0.477 \mathrm{a}$ & $0.446 \mathrm{~b}$ & 0.583 & 0.818 & $-0.554^{d}$ & $0.531 \mathrm{a}$ & $0.654 \mathrm{~b}$ & $0.461 \mathrm{~b}$ & 1.151 & -0.346 \\
\hline Papua Barat & $0.882 \mathrm{a}$ & $0.275 b$ & $0.135 b$ & 6.531 & $-0.725^{\mathrm{d}}$ & $0.904 a$ & $0.307 \mathrm{~b}$ & $0.112 \mathrm{c}$ & 8.049 & $-0.693^{d}$ & $0.837 \mathrm{a}$ & $0.476 \mathrm{a}$ & 0.199 & 4.206 & $-0.524^{d}$ & $0.906 \mathrm{a}$ & $0.638 \mathrm{a}$ & $0.101 \mathrm{c}$ & 8.977 & $-0.362^{\mathrm{d}}$ \\
\hline Kepulauan Riau & $0.969 \mathrm{a}$ & $0.313 \mathrm{a}$ & 0.022 & 44.424 & $-0.687^{\mathrm{d}}$ & $0.987 \mathrm{a}$ & $0.291 \mathrm{~b}$ & 0.006 & 176.603 & $-0.709^{\mathrm{d}}$ & $0.978 \mathrm{a}$ & $0.460 \mathrm{a}$ & 0.015 & 65.617 & $-0.540^{\mathrm{d}}$ & $0.976 \mathrm{a}$ & $0.614 \mathrm{a}$ & 0.013 & 75.068 & $-0.386^{d}$ \\
\hline
\end{tabular}


Lampiran 3. Hasil Pendugaan Regresi Model Ravallion Komoditi Kedelai di Indonesia

\begin{tabular}{|c|c|c|c|c|c|c|c|c|c|c|c|c|c|c|c|c|c|c|c|c|}
\hline \multirow{2}{*}{$\begin{array}{l}\text { Provinsi Acuan } \\
\text { Provinsi Pengikut }\end{array}$} & \multicolumn{5}{|c|}{ Jawa Barat } & \multicolumn{5}{|c|}{ Jawa Timur } & \multicolumn{5}{|c|}{ Jawa Tengah } & \multicolumn{5}{|c|}{ Sulawesi Selatan } \\
\hline & $b_{1}$ & $b_{2}$ & $b_{3}$ & IMC & $b_{2}-1$ & $b_{1}$ & $b_{2}$ & $b_{3}$ & IMC & $b_{2}-1$ & $b_{1}$ & $b_{2}$ & $b_{3}$ & IMC & $b_{2}-1$ & $b_{1}$ & $b_{2}$ & $b_{3}$ & IMC & $b_{2}-1$ \\
\hline Jawa Barat & & & & & & $0.952 \mathrm{a}$ & 0.142 & 0.060 & 15.82 & $-0.858^{d}$ & $0.957 \mathrm{a}$ & 0.025 & 0.055 & 17.34 & $-0.975^{d}$ & $0.970 \mathrm{a}$ & 0.161 & 0.036 & 27.23 & $-0.839^{\mathrm{d}}$ \\
\hline Jawa Timur & $0.982 \mathrm{a}$ & 0.037 & 0.012 & 82.73 & $-0.963^{\mathrm{d}}$ & & & & & & $0.933 \mathrm{a}$ & 0.032 & 0.065 & 14.29 & $-0.968^{d}$ & $0.987 \mathrm{a}$ & 0.008 & 0.008 & 120.19 & $-0.992^{d}$ \\
\hline Jawa Tengah & $0.777 \mathrm{a}$ & 0.060 & 0.182 & 4.28 & $-0.940^{d}$ & $0.494 a$ & 0.258 & 0.491a & 1.01 & $-0.742^{d}$ & & & & & & $0.843 a$ & 0.129 & 0.137 & 6.16 & $-0.871^{d}$ \\
\hline Sulawesi Selatan & $0.926 \mathrm{a}$ & 0.264 & 0.066 & 13.95 & $-0.736^{d}$ & $0.892 \mathrm{a}$ & 0.049 & $0.116 a$ & 7.71 & $-0.951^{d}$ & 0.911a & 0.085 & $0.098 \mathrm{a}$ & 9.33 & $-0.915^{\mathrm{d}}$ & & & & & \\
\hline Sumatera Utara & $0.917 \mathrm{a}$ & $0.334 \mathrm{a}$ & $0.066 \mathrm{~b}$ & 13.93 & $-0.666^{d}$ & $0.997 \mathrm{a}$ & $0.505 \mathrm{a}$ & 0.004 & 221.82 & $-0.495^{d}$ & 0.956a & 0.071 & 0.043 & 22.30 & $-0.929^{d}$ & $0.982 \mathrm{a}$ & -0.028 & 0.016 & 62.83 & $-1.028^{d}$ \\
\hline Sumatera Selatan & $0.771 \mathrm{a}$ & $0.297 \mathrm{a}$ & $0.204 a$ & 3.78 & $-0.703^{d}$ & $0.826 \mathrm{a}$ & 0.100 & $0.184 \mathrm{~b}$ & 4.49 & $-0.900^{d}$ & $0.843 a$ & $0.276 \mathrm{a}$ & 0.171 & 4.92 & $-0.724^{d}$ & $0.921 \mathrm{a}$ & 0.022 & 0.079 & 11.65 & $-0.978^{d}$ \\
\hline Lampung & $0.918 \mathrm{a}$ & $0.226 \mathrm{a}$ & $0.062 \mathrm{c}$ & 14.87 & $-0.774^{d}$ & $0.966 \mathrm{a}$ & $0.229 \mathrm{c}$ & 0.030 & 32.22 & $-0.771^{d}$ & $0.948 \mathrm{a}$ & 0.036 & 0.047 & 20.16 & $-0.964^{d}$ & $1.004 \mathrm{a}$ & 0.073 & -0.006 & 177.87 & $-0.927^{d}$ \\
\hline Jakarta & $0.884 a$ & -0.140 & $0.109 \mathrm{c}$ & 8.14 & $-1.140^{d}$ & $0.948 \mathrm{a}$ & -0.071 & 0.057 & 16.59 & $-1.071^{d}$ & 0.973a & $0.225 \mathrm{a}$ & 0.032 & 30.82 & $-0.775^{d}$ & $0.990 \mathrm{a}$ & 0.012 & 0.011 & 92.09 & $-0.988^{d}$ \\
\hline Aceh & $0.800 \mathrm{a}$ & $0.407 \mathrm{a}$ & $0.201 \mathrm{a}$ & 3.98 & $-0.593^{\mathrm{d}}$ & $0.927 \mathrm{a}$ & 0.175 & 0.086 & 10.75 & $-0.825^{\mathrm{d}}$ & 0.944a & 0.041 & 0.067 & 14.08 & $-0.959^{d}$ & $0.923 a$ & 0.378 & $0.084 \mathrm{c}$ & 10.99 & $-0.622^{d}$ \\
\hline Sumatera Barat & $0.902 \mathrm{a}$ & 0.310a & 0.085 & 10.64 & $-0.690^{d}$ & 0.936a & -0.029 & 0.065 & 14.37 & $-1.029^{\mathrm{d}}$ & $0.921 \mathrm{a}$ & 0.091 & 0.083 & 11.05 & $-0.909^{\mathrm{d}}$ & $0.943 a$ & 0.052 & 0.055 & 17.25 & $-0.948^{d}$ \\
\hline Riau & $0.915 \mathrm{a}$ & 0.123 & 0.072 & 12.64 & $-0.877^{d}$ & $0.873 \mathrm{a}$ & 0.193 & 0.130 & 6.73 & $-0.807^{d}$ & $0.894 a$ & 0.067 & 0.110 & 8.14 & $-0.933^{\mathrm{d}}$ & $0.968 \mathrm{a}$ & 0.266 & 0.028 & 34.98 & $-0.734^{d}$ \\
\hline Jambi & $0.853 \mathrm{a}$ & $0.400 \mathrm{a}$ & $0.122 \mathrm{~b}$ & 7.00 & $-0.600^{d}$ & $1.001 \mathrm{a}$ & $0.302 \mathrm{c}$ & 0.000 & $3,166.36$ & $-0.698^{d}$ & $0.962 \mathrm{a}$ & 0.083 & 0.038 & 25.26 & $-0.917^{d}$ & $0.960 \mathrm{a}$ & 0.134 & 0.037 & 26.05 & $-0.866^{\mathrm{d}}$ \\
\hline Bengkulu & $0.964 \mathrm{a}$ & -0.144 & 0.027 & 35.39 & $-1.144^{d}$ & $0.933 \mathrm{a}$ & 0.080 & 0.062 & 15.05 & $-0.920^{d}$ & $0.902 \mathrm{a}$ & 0.089 & $0.095 \mathrm{c}$ & 9.48 & $-0.911^{\mathrm{d}}$ & $0.980 \mathrm{a}$ & -0.202 & 0.014 & 67.75 & $-1.202^{d}$ \\
\hline Yogyakarta & $0.835 \mathrm{a}$ & 0.159 & $0.132 \mathrm{~b}$ & 6.31 & $-0.841^{d}$ & $0.918 \mathrm{a}$ & 0.134 & 0.077 & 11.88 & $-0.866^{d}$ & $0.945 \mathrm{a}$ & 0.082 & 0.051 & 18.40 & $-0.918^{d}$ & $0.963 \mathrm{a}$ & -0.049 & 0.031 & 31.06 & $-1.049^{d}$ \\
\hline Bali & $0.785 \mathrm{a}$ & 0.271 & $0.189 \mathrm{~b}$ & 4.16 & $-0.729^{d}$ & $0.820 \mathrm{a}$ & 0.354 & $0.188 \mathrm{~b}$ & 4.37 & $-0.646^{d}$ & $0.853 \mathrm{a}$ & 0.078 & 0.156 & 5.47 & $-0.922^{\mathrm{d}}$ & $0.881 \mathrm{a}$ & 0.436 & 0.114 & 7.74 & $-0.564^{d}$ \\
\hline NTB & $0.909 \mathrm{a}$ & $0.239 \mathrm{~b}$ & 0.073 & 12.39 & $-0.761^{d}$ & $1.028 \mathrm{a}$ & 0.271 & -0.023 & 45.60 & $-0.729^{\mathrm{d}}$ & $0.997 \mathrm{a}$ & 0.066 & 0.006 & 159.47 & $-0.934^{d}$ & $0.997 \mathrm{a}$ & 0.164 & 0.005 & 193.01 & $-0.836^{d}$ \\
\hline NTT & $0.937 \mathrm{a}$ & -0.093 & $0.062 \mathrm{~b}$ & 15.04 & $-1.093^{d}$ & $0.924 \mathrm{a}$ & -0.176 & 0.088 & 10.55 & $-1.176^{d}$ & $0.840 \mathrm{a}$ & 0.094 & $0.197 \mathrm{a}$ & 4.25 & $-0.906^{\mathrm{d}}$ & $0.942 \mathrm{a}$ & -0.084 & 0.061 & 15.49 & $-1.084^{d}$ \\
\hline Gorontalo & $0.575 \mathrm{a}$ & $0.787 \mathrm{~b}$ & $0.489 \mathrm{a}$ & 1.18 & $-0.213^{d}$ & $0.755 \mathrm{a}$ & $1.200 \mathrm{c}$ & $0.335 \mathrm{a}$ & 2.25 & 0.200 & $0.779 \mathrm{a}$ & $0.462 c$ & $0.307 \mathrm{~b}$ & 2.54 & $-0.538^{d}$ & $0.861 \mathrm{a}$ & -0.268 & 0.173 & 4.97 & $-1.268^{d}$ \\
\hline Kalimantan Barat & 0.935a & $0.226 \mathrm{a}$ & $0.049 \mathrm{~b}$ & 18.93 & $-0.774^{d}$ & $0.860 \mathrm{a}$ & 0.236 & $0.132 \mathrm{~b}$ & 6.51 & $-0.764^{d}$ & $0.959 \mathrm{a}$ & 0.028 & 0.036 & 26.40 & $-0.972^{\mathrm{d}}$ & $0.990 \mathrm{a}$ & -0.004 & 0.005 & 187.74 & $-1.004^{d}$ \\
\hline Kalimantan Tengah & $0.987 \mathrm{a}$ & 0.043 & 0.005 & 182.83 & $-0.957^{d}$ & 0.976a & 0.019 & 0.019 & 51.63 & $-0.981^{d}$ & $0.971 \mathrm{a}$ & 0.007 & 0.025 & 39.25 & $-0.993^{d}$ & $0.974 \mathrm{a}$ & 0.036 & 0.019 & 51.51 & $-0.964^{d}$ \\
\hline Kalimantan Selatan & $0.914 \mathrm{a}$ & 0.024 & $0.075 b$ & 12.22 & $-0.976^{d}$ & $0.973 \mathrm{a}$ & -0.049 & 0.028 & 35.02 & $-1.049^{d}$ & $0.967 \mathrm{a}$ & -0.006 & 0.035 & 27.59 & $-1.006^{d}$ & $0.965 \mathrm{a}$ & -0.102 & 0.034 & 28.73 & $-1.102^{d}$ \\
\hline Kalimantan Timur & $0.905 \mathrm{a}$ & 0.150 & $0.088 \mathrm{c}$ & 10.24 & $-0.850^{\mathrm{d}}$ & $0.967 \mathrm{a}$ & 0.131 & 0.036 & 26.81 & $-0.869^{\mathrm{d}}$ & $0.925 \mathrm{a}$ & 0.078 & 0.084 & 11.08 & $-0.922^{\mathrm{d}}$ & $0.909 \mathrm{a}$ & $0.180 \mathrm{~b}$ & $0.093 \mathrm{~b}$ & 9.79 & $-0.820^{\mathrm{d}}$ \\
\hline Sulawesi Utara & $0.786 a$ & $0.397 \mathrm{~b}$ & $0.203 \mathrm{a}$ & 3.87 & $-0.603^{d}$ & $0.872 \mathrm{a}$ & $0.608 \mathrm{c}$ & 0.145 & 6.02 & $-0.392^{d}$ & $0.873 \mathrm{a}$ & 0.048 & $0.146 \mathrm{a}$ & 5.99 & $-0.952^{\mathrm{d}}$ & $0.914 \mathrm{a}$ & 0.021 & $0.089 \mathrm{c}$ & 10.23 & $-0.979^{d}$ \\
\hline Sulawesi Tengah & 0.891a & 0.201 & $0.127 \mathrm{c}$ & 7.04 & $-0.799^{d}$ & $0.713 \mathrm{a}$ & -0.018 & $0.405 \mathrm{a}$ & 1.76 & $-1.018^{d}$ & $0.721 \mathrm{a}$ & 0.243 & $0.402 \mathrm{a}$ & 1.80 & $-0.757^{d}$ & $0.831 \mathrm{a}$ & $0.507 \mathrm{a}$ & $0.220 \mathrm{a}$ & 3.78 & $-0.493^{d}$ \\
\hline Sulawesi Tenggara & $0.872 \mathrm{a}$ & $0.414 b$ & $0.144 \mathrm{c}$ & 6.06 & $-0.586^{d}$ & $0.927 \mathrm{a}$ & $-1.161 \mathrm{a}$ & 0.094 & 9.91 & $-2.161^{d}$ & $0.940 \mathrm{a}$ & 0.052 & 0.082 & 11.45 & $-0.948^{d}$ & $0.906 \mathrm{a}$ & 0.136 & $0.116 \mathrm{c}$ & 7.85 & $-0.864^{d}$ \\
\hline Maluku & $0.837 \mathrm{a}$ & 0.189 & 0.180 & 4.65 & $-0.811^{\mathrm{d}}$ & $0.608 \mathrm{a}$ & 0.176 & $0.527 \mathrm{a}$ & 1.15 & $-0.824^{d}$ & $0.683 a$ & $0.261 \mathrm{a}$ & $0.434 \mathrm{a}$ & 1.57 & $-0.739^{d}$ & $0.797 \mathrm{a}$ & 0.143 & 0.248 & 3.22 & $-0.857^{d}$ \\
\hline Papua & $0.852 \mathrm{a}$ & 0.124 & $0.203 b$ & 4.19 & $-0.876^{d}$ & $0.955 \mathrm{a}$ & 0.349 & 0.076 & 12.52 & $-0.651^{d}$ & $0.950 \mathrm{a}$ & 0.039 & 0.085 & 11.17 & $-0.961^{\mathrm{d}}$ & 0.950a & 0.088 & 0.078 & 12.19 & $-0.912^{\mathrm{d}}$ \\
\hline Banten & $0.895 \mathrm{a}$ & $0.230 \mathrm{~b}$ & $0.090 \mathrm{c}$ & 9.89 & $-0.770^{\mathrm{d}}$ & $0.896 \mathrm{a}$ & $0.318 \mathrm{c}$ & 0.106 & 8.42 & $-0.682^{d}$ & $0.881 \mathrm{a}$ & -0.018 & $0.123 \mathrm{a}$ & 7.14 & $-1.018^{d}$ & $0.952 \mathrm{a}$ & 0.059 & 0.045 & 21.23 & $-0.941^{d}$ \\
\hline Bangka Belitung & $0.883 \mathrm{a}$ & $0.384 a$ & $0.094 \mathrm{c}$ & 9.42 & $-0.616^{d}$ & $0.958 \mathrm{a}$ & 0.162 & 0.039 & 24.67 & $-0.838^{\mathrm{d}}$ & $0.958 \mathrm{a}$ & 0.052 & 0.040 & 23.93 & $-0.948^{d}$ & 0.981a & 0.119 & 0.015 & 63.35 & $-0.881^{\mathrm{d}}$ \\
\hline Maluku Utara & $0.923 \mathrm{a}$ & -0.205 & 0.118 & 7.82 & $-1.205^{d}$ & $0.911 \mathrm{a}$ & -0.489 & $0.160 \mathrm{c}$ & 5.71 & $-1.489^{d}$ & $0.929 \mathrm{a}$ & -0.026 & 0.130 & 7.15 & $-1.026^{d}$ & $0.929 \mathrm{a}$ & -0.062 & 0.117 & 7.94 & $-1.062^{d}$ \\
\hline Sulawesi Barat & $0.874 a$ & 0.331 & $0.136 \mathrm{~b}$ & 6.42 & $-0.669^{d}$ & $0.897 \mathrm{a}$ & 0.488 & $0.134 b$ & 6.69 & $-0.512^{\mathrm{d}}$ & $0.860 \mathrm{a}$ & $-0.468 \mathrm{a}$ & $0.183 \mathrm{a}$ & 4.70 & $-1.468^{d}$ & $0.958 \mathrm{a}$ & 0.232 & 0.051 & 18.70 & $-0.768^{d}$ \\
\hline Papua Barat & $0.904 \mathrm{a}$ & $0.296 \mathrm{a}$ & 0.113 & 8.02 & $-0.704^{d}$ & $0.807 \mathrm{a}$ & $0.584 \mathrm{a}$ & $0.294 \mathrm{~b}$ & 2.75 & $-0.416^{d}$ & $0.844 \mathrm{a}$ & $0.838 \mathrm{a}$ & $0.239 \mathrm{c}$ & 3.53 & $-0.162^{d}$ & $0.968 \mathrm{a}$ & 0.108 & 0.046 & 20.87 & $-0.892^{d}$ \\
\hline Kepulauan Riau & $0.842 \mathrm{a}$ & $0.417 \mathrm{a}$ & $0.126 \mathrm{~b}$ & 6.66 & $-0.583^{d}$ & $1.023 \mathrm{a}$ & 0.177 & -0.018 & 55.28 & $-0.823^{\mathrm{d}}$ & $0.993 \mathrm{a}$ & $0.958 \mathrm{a}$ & 0.011 & 91.20 & $-0.042^{\mathrm{d}}$ & $0.974 \mathrm{a}$ & $0.170 \mathrm{c}$ & 0.025 & 39.58 & $-0.830^{\mathrm{d}}$ \\
\hline
\end{tabular}


Lampiran 3. Hasil Pendugaan Regresi Model Ravallion Komoditi Kedelai di Indonesia

\begin{tabular}{|c|c|c|c|c|c|c|c|c|c|c|c|c|c|c|c|c|c|c|c|c|}
\hline \multirow{2}{*}{$\begin{array}{l}\text { Provinsi Acuan } \\
\text { Provinsi Pengikut }\end{array}$} & \multicolumn{5}{|c|}{ Sumatera Utara } & \multicolumn{5}{|c|}{ Sumatera Selatan } & \multicolumn{5}{|c|}{ Lampung } & \multicolumn{5}{|c|}{ Jakarta } \\
\hline & $b_{1}$ & $b_{2}$ & $b_{3}$ & IMC & $b_{2}-1$ & $b_{1}$ & $b_{2}$ & $b_{3}$ & IMC & $b_{2}-1$ & $b_{1}$ & $b_{2}$ & $b_{3}$ & IMC & $b_{2}-1$ & $b_{1}$ & $b_{2}$ & $b_{3}$ & IMC & $b_{2}-1$ \\
\hline Jawa Barat & $0.915 \mathrm{a}$ & $0.775 \mathrm{a}$ & $0.109 \mathrm{c}$ & 8.36 & -0.225 & $0.931 \mathrm{a}$ & $0.188 \mathrm{c}$ & 0.082 & 11.40 & $-0.812^{\mathrm{d}}$ & $0.857 \mathrm{a}$ & $0.924 \mathrm{a}$ & 0.190 & 4.52 & -0.076 & $0.798 \mathrm{a}$ & 0.248 & $0.222 \mathrm{~b}$ & 3.59 & $-1.248^{d}$ \\
\hline Jawa Timur & $0.966 \mathrm{a}$ & $0.293 \mathrm{a}$ & 0.032 & 30.01 & $-0.707^{d}$ & $1.022 \mathrm{a}$ & 0.016 & 0.026 & 39.89 & $-0.984^{\mathrm{d}}$ & $0.960 \mathrm{a}$ & $0.245 c$ & 0.041 & 23.67 & $-0.755^{d}$ & $0.985 \mathrm{a}$ & 0.035 & 0.011 & 91.41 & $-1.035^{\mathrm{d}}$ \\
\hline Jawa Tengah & $0.642 \mathrm{a}$ & 0.358 & $0.363 \mathrm{a}$ & 1.77 & $-0.642^{d}$ & $0.846 \mathrm{a}$ & $0.443 \mathrm{a}$ & $0.139 \mathrm{a}$ & 6.10 & $-0.557^{\mathrm{d}}$ & $0.616 \mathrm{a}$ & 0.333 & $0.406 \mathrm{a}$ & 1.52 & $-0.667^{\mathrm{d}}$ & $0.730 \mathrm{a}$ & $0.969 \mathrm{a}$ & $0.238 \mathrm{a}$ & 3.07 & -0.031 \\
\hline Sulawesi Selatan & $0.929 a$ & 0.102 & 0.080 & 11.64 & $-1.102^{d}$ & $0.952 \mathrm{a}$ & 0.022 & 0.049 & 19.28 & $-0.978^{d}$ & $0.906 \mathrm{a}$ & 0.484 & $0.111 \mathrm{a}$ & 8.13 & $-0.516^{\mathrm{d}}$ & $0.889 \mathrm{a}$ & 0.035 & $0.110 \mathrm{~b}$ & 8.08 & $-0.965^{\mathrm{d}}$ \\
\hline Sumatera Utara & & & & & & $0.909 \mathrm{a}$ & $0.217 \mathrm{a}$ & $0.082 \mathrm{alc}$ & 11.03 & $-0.783^{\mathrm{d}}$ & $0.880 \mathrm{a}$ & $0.556 \mathrm{a}$ & $0.126 \mathrm{a}$ & 6.98 & $-0.444^{\mathrm{d}}$ & $0.916 \mathrm{a}$ & $-0.22 b$ & $0.073 \mathrm{~b}$ & 12.49 & $-1.226^{d}$ \\
\hline Sumatera Selatan & $0.725 \mathrm{a}$ & $0.764 a$ & $0.303 \mathrm{a}$ & 2.40 & -0.236 & & & & & & $0.710 \mathrm{a}$ & 0.072 & $0.331 \mathrm{a}$ & 2.15 & $-0.928^{\mathrm{d}}$ & $0.797 \mathrm{a}$ & 0.137 & $0.196 \mathrm{a}$ & 4.06 & $-0.863^{\mathrm{d}}$ \\
\hline Lampung & $0.956 \mathrm{a}$ & $0.318 \mathrm{a}$ & 0.040 & 23.61 & $-0.682^{d}$ & $1.004 \mathrm{a}$ & 0.012 & 0.006 & 169.07 & $-0.988^{d}$ & & & & & & $0.911 \mathrm{a}$ & -0.098 & $0.074 \mathrm{c}$ & 12.31 & $-1.098^{\mathrm{d}}$ \\
\hline Jakarta & $0.973 \mathrm{a}$ & $-0.291 \mathrm{c}$ & 0.032 & 30.71 & $-1.291^{\mathrm{d}}$ & $0.994 \mathrm{a}$ & 0.047 & 0.007 & 144.55 & $-0.953^{\mathrm{d}}$ & $0.912 \mathrm{a}$ & -0.223 & 0.105 & 8.72 & $-1.223^{\mathrm{d}}$ & & & & & \\
\hline Aceh & $0.836 \mathrm{a}$ & 0.347 & $0.204 \mathrm{~b}$ & 4.11 & $-0.653^{d}$ & $0.887 \mathrm{a}$ & $0.309 \mathrm{a}$ & 0.127 & 6.96 & $-0.691^{\mathrm{d}}$ & $0.690 \mathrm{a}$ & 0.328 & $0.401 \mathrm{a}$ & 1.72 & $-0.672^{\mathrm{d}}$ & $0.883 a$ & -0.288 & $0.128 \mathrm{a}$ & 6.89 & $-1.288^{d}$ \\
\hline Sumatera Barat & $0.878 \mathrm{a}$ & $0.534 a$ & $0.133 \mathrm{~b}$ & 6.62 & $-0.466^{d}$ & $0.899 \mathrm{a}$ & $0.216 \mathrm{a}$ & $0.101 \mathrm{ab}$ & 8.93 & $-0.784^{\mathrm{d}}$ & $0.875 \mathrm{a}$ & $0.448 b$ & $0.142 b$ & 6.15 & $-0.552^{\mathrm{d}}$ & $0.842 \mathrm{a}$ & $-0.326 \mathrm{a}$ & $0.151 \mathrm{a}$ & 5.58 & $-1.326^{d}$ \\
\hline Riau & $0.860 \mathrm{a}$ & $0.413 b$ & 0.149 & 5.79 & $-0.587^{d}$ & $0.925 \mathrm{a}$ & $0.187 \mathrm{a}$ & 0.072 & 12.92 & $-0.813^{\mathrm{d}}$ & $0.786 a$ & 0.295 & $0.241 \mathrm{a}$ & 3.27 & $-0.705^{d}$ & $0.857 \mathrm{a}$ & 0.016 & $0.135 \mathrm{~b}$ & 6.36 & $-0.984^{\mathrm{d}}$ \\
\hline Jambi & $0.970 \mathrm{a}$ & $0.628 \mathrm{a}$ & 0.031 & 31.32 & $-0.372^{d}$ & $0.983 \mathrm{a}$ & $0.227 \mathrm{a}$ & 0.014 & 67.98 & $-0.773^{d}$ & $0.888 \mathrm{a}$ & $0.676 \mathrm{a}$ & 0.122 & 7.29 & -0.324 & $0.854 \mathrm{a}$ & -0.121 & $0.133 b$ & 6.43 & $-1.121^{d}$ \\
\hline Bengkulu & $0.968 \mathrm{a}$ & $0.373 b$ & 0.029 & 33.05 & $-0.627^{d}$ & $0.959 \mathrm{a}$ & 0.045 & 0.035 & 27.20 & $-0.955^{d}$ & $0.962 \mathrm{a}$ & -0.045 & 0.037 & 26.33 & $-1.045^{d}$ & 0.94la & -0.121 & 0.050 & 18.88 & $-1.121^{d}$ \\
\hline Yogyakarta & $0.842 \mathrm{a}$ & $0.471 \mathrm{a}$ & $0.157 \mathrm{a}$ & 5.36 & $-0.529^{d}$ & $0.908 \mathrm{a}$ & $0.273 \mathrm{a}$ & 0.082 & 11.14 & $-0.727^{d}$ & $0.683 \mathrm{a}$ & $0.402 c$ & $0.330 \mathrm{a}$ & 2.07 & $-0.598^{d}$ & $0.858 \mathrm{a}$ & 0.174 & $0.123 b$ & 6.98 & $-0.826^{\mathrm{d}}$ \\
\hline Bali & $0.818 \mathrm{a}$ & 0.299 & $0.199 \mathrm{a}$ & 4.12 & $-0.701^{d}$ & $0.846 \mathrm{a}$ & $0.247 \mathrm{c}$ & $0.155 \mathrm{a}$ & 5.47 & $-0.753^{\mathrm{d}}$ & $0.761 \mathrm{a}$ & -0.202 & $0.270 \mathrm{a}$ & 2.82 & $-1.202^{\mathrm{d}}$ & $0.652 \mathrm{a}$ & -0.120 & $0.333 \mathrm{a}$ & 1.96 & $-1.120^{\mathrm{d}}$ \\
\hline NTB & $0.982 \mathrm{a}$ & $0.539 \mathrm{a}$ & 0.021 & 47.78 & $-0.461^{d}$ & $1.022 \mathrm{a}$ & 0.088 & 0.018 & 56.17 & $-0.912^{\mathrm{d}}$ & $0.963 \mathrm{a}$ & $0.547 \mathrm{a}$ & 0.042 & 23.11 & $-0.453^{d}$ & $0.922 \mathrm{a}$ & 0.048 & 0.070 & 13.21 & $-1.048^{d}$ \\
\hline NTT & $0.933 \mathrm{a}$ & 0.032 & $0.081 \mathrm{a}$ & 11.54 & $-0.968^{d}$ & $0.947 \mathrm{a}$ & 0.052 & $0.059 \mathrm{c}$ & 16.18 & $-0.948^{\mathrm{d}}$ & $0.938 \mathrm{a}$ & -0.180 & $0.077 \mathrm{~b}$ & 12.21 & $-1.180^{\mathrm{d}}$ & $0.935 \mathrm{a}$ & 0.105 & $0.069 \mathrm{~b}$ & 13.53 & $-0.895^{\mathrm{d}}$ \\
\hline Gorontalo & $0.741 \mathrm{a}$ & $1.172 \mathrm{~b}$ & $0.369 \mathrm{a}$ & 2.01 & 0.172 & $0.779 \mathrm{a}$ & 0.273 & $0.289 \mathrm{~b}$ & 2.70 & $-0.727^{\mathrm{d}}$ & $0.557 \mathrm{a}$ & $2.085 \mathrm{a}$ & $0.661 \mathrm{a}$ & 0.84 & 1.085 & $0.605 \mathrm{a}$ & 0.356 & $0.493 \mathrm{a}$ & 1.23 & $-0.644^{d}$ \\
\hline Kalimantan Barat & $0.887 \mathrm{a}$ & $0.372 \mathrm{a}$ & $0.111 \mathrm{c}$ & 7.98 & $-0.628^{d}$ & $0.964 a$ & 0.095 & 0.029 & 33.37 & $-0.905^{d}$ & $0.885 \mathrm{a}$ & $0.461 \mathrm{a}$ & $0.119 \mathrm{~b}$ & 7.45 & $-0.539^{d}$ & $0.941 \mathrm{a}$ & -0.094 & 0.049 & 19.03 & $-1.094^{d}$ \\
\hline Kalimantan Tengah & $0.991 \mathrm{a}$ & 0.083 & 0.001 & 1,024 & $-0.917^{d}$ & $0.989 \mathrm{a}$ & 0.035 & 0.003 & 287.15 & $-0.965^{\mathrm{d}}$ & $0.986 \mathrm{a}$ & 0.069 & 0.008 & 120.67 & $-0.931^{\mathrm{d}}$ & $0.985 \mathrm{a}$ & -0.040 & 0.008 & 125.79 & $-1.040^{\mathrm{d}}$ \\
\hline Kalimantan Selatan & $0.800 \mathrm{a}$ & $0.203 \mathrm{c}$ & $0.213 \mathrm{a}$ & 3.75 & $-0.797^{d}$ & $0.909 \mathrm{a}$ & $0.145 b$ & $0.089 \mathrm{a}$ & 10.18 & $-0.855^{d}$ & $0.845 \mathrm{a}$ & -0.236 & $0.172 \mathrm{a}$ & 4.91 & $-1.236^{d}$ & $0.912 \mathrm{a}$ & 0.007 & $0.083 \mathrm{~b}$ & 10.97 & $-0.993^{\mathrm{d}}$ \\
\hline Kalimantan Timur & $0.937 \mathrm{a}$ & $0.422 \mathrm{a}$ & 0.072 & 13.02 & $-0.578^{d}$ & $0.970 \mathrm{a}$ & 0.128 & 0.030 & 31.98 & $-0.872^{\mathrm{d}}$ & $0.873 \mathrm{a}$ & 0.322 & $0.153 b$ & 5.71 & $-0.678^{d}$ & $0.840 \mathrm{a}$ & -0.091 & $0.163 \mathrm{a}$ & 5.16 & $-1.091^{\mathrm{d}}$ \\
\hline Sulawesi Utara & $0.829 \mathrm{a}$ & $0.957 \mathrm{a}$ & $0.202 \mathrm{~b}$ & 4.10 & $-0.043^{\mathrm{d}}$ & $0.848 \mathrm{a}$ & $0.325 \mathrm{a}$ & $0.163 b$ & 5.19 & $-0.675^{\mathrm{d}}$ & $0.750 \mathrm{a}$ & $0.718 b$ & $0.308 \mathrm{a}$ & 2.43 & -0.282 & $0.794 a$ & $-0.48 b$ & $0.214 \mathrm{a}$ & 3.71 & $-1.483^{\mathrm{d}}$ \\
\hline Sulawesi Tengah & $0.881 \mathrm{a}$ & 0.085 & $0.172 \mathrm{a}$ & 5.12 & $-0.915^{d}$ & $0.933 \mathrm{a}$ & $0.425 b$ & 0.084 & 11.06 & $-0.575^{d}$ & $0.845 \mathrm{a}$ & -0.078 & $0.236 \mathrm{~b}$ & 3.59 & $-1.078^{d}$ & $0.824 a$ & 0.092 & $0.227 \mathrm{~b}$ & 3.64 & $-0.908^{d}$ \\
\hline Sulawesi Tenggara & $0.955 \mathrm{a}$ & 0.165 & 0.063 & 15.16 & $-1.165^{d}$ & $0.931 \mathrm{a}$ & 0.015 & 0.090 & 10.38 & $-0.985^{\mathrm{d}}$ & $0.918 \mathrm{a}$ & $0.698 \mathrm{~b}$ & 0.120 & 7.62 & -0.302 & $0.817 \mathrm{a}$ & 0.112 & $0.224 b$ & 3.64 & $-0.888^{d}$ \\
\hline Maluku & $0.822 \mathrm{a}$ & 0.356 & $0.245 \mathrm{a}$ & 3.36 & $-0.644^{d}$ & $0.864 a$ & $0.410 \mathrm{a}$ & $0.168 \mathrm{a}$ & 5.14 & $-0.590^{\mathrm{d}}$ & $0.818 \mathrm{a}$ & 0.332 & $0.260 \mathrm{a}$ & 3.14 & $-0.668^{d}$ & 0.791a & 0.376 & $0.255 \mathrm{a}$ & 3.10 & $-1.376^{d}$ \\
\hline Papua & $0.944 a$ & 0.410 & 0.099 & 9.55 & $-0.590^{d}$ & $0.955 \mathrm{a}$ & 0.188 & 0.072 & 13.26 & $-0.812^{\mathrm{d}}$ & $0.917 \mathrm{a}$ & 0.602 & $0.150 \mathrm{c}$ & 6.12 & $-0.398^{d}$ & $0.933 \mathrm{a}$ & -0.174 & 0.102 & 9.10 & $-1.174^{d}$ \\
\hline Banten & $0.941 \mathrm{a}$ & $0.315 b$ & 0.063 & 14.95 & $-0.685^{d}$ & $0.974 \mathrm{a}$ & $0.138 \mathrm{a}$ & 0.024 & 40.75 & $-0.862^{\mathrm{d}}$ & $0.835 \mathrm{a}$ & $0.504 a$ & $0.185 b$ & 4.53 & $-0.496^{d}$ & $0.871 \mathrm{a}$ & -0.177 & $0.12 \mathrm{lb}$ & 7.17 & $-1.177^{d}$ \\
\hline Bangka Belitung & $0.955 \mathrm{a}$ & $0.609 \mathrm{a}$ & 0.043 & 22.16 & $-0.391^{d}$ & $0.975 \mathrm{a}$ & $0.245 \mathrm{a}$ & 0.020 & 49.41 & $-0.755^{d}$ & $0.894 \mathrm{a}$ & $0.783 \mathrm{a}$ & 0.112 & 8.01 & -0.217 & $0.865 \mathrm{a}$ & -0.058 & $0.119 \mathrm{a}$ & 7.26 & $-1.058^{d}$ \\
\hline Maluku Utara & $0.934 \mathrm{a}$ & $2.24 \mathrm{a}$ & 0.123 & 7.60 & $-3.243^{d}$ & $0.942 \mathrm{a}$ & 0.097 & 0.098 & 9.60 & $-0.903^{\mathrm{d}}$ & $0.929 \mathrm{a}$ & 0.258 & 0.138 & 6.71 & $-0.742^{\mathrm{d}}$ & $0.924 \mathrm{a}$ & 0.252 & 0.124 & 7.46 & -0.748 \\
\hline Sulawesi Barat & $0.865 \mathrm{a}$ & 0.362 & $0.182 \mathrm{~b}$ & 4.76 & $-0.638^{d}$ & $0.900 \mathrm{a}$ & -0.047 & $0.126 c$ & 7.15 & $-1.047^{d}$ & $0.837 \mathrm{a}$ & $1.218 \mathrm{~b}$ & $0.229 \mathrm{a}$ & 3.66 & 0.218 & $0.845 \mathrm{a}$ & $-0.88 \mathrm{a}$ & $0.184 a$ & 4.59 & $-1.881^{\mathrm{d}}$ \\
\hline Papua Barat & $0.904 a$ & $0.538 \mathrm{a}$ & 0.145 & 6.24 & $-0.462^{d}$ & $1.046 \mathrm{a}$ & 0.050 & 0.064 & 16.26 & $-0.950^{d}$ & $0.880 \mathrm{a}$ & $0.695 \mathrm{a}$ & $0.188 \mathrm{a}$ & 4.68 & -0.305 & $1.047 \mathrm{a}$ & $-0.64 \mathrm{a}$ & 0.059 & 17.68 & $-1.645^{d}$ \\
\hline Kepulauan Riau & $0.941 \mathrm{a}$ & $0.823 \mathrm{a}$ & 0.061 & 15.42 & $-0.177^{d}$ & $0.950 \mathrm{a}$ & 0.162 & 0.048 & 19.92 & $-0.838^{\mathrm{d}}$ & $0.902 \mathrm{a}$ & $0.671 \mathrm{a}$ & 0.106 & 8.48 & -0.329 & $0.956 \mathrm{a}$ & $-0.488 b$ & 0.042 & 23.01 & $-1.488^{\mathrm{d}}$ \\
\hline
\end{tabular}

